ALEXANDRE CAMARGO ATALIBA

\title{
Estudo de Borrelia spp. no Brasil
}




\section{ALEXANDRE CAMARGO ATALIBA}

\section{Estudo de Borrelia spp. no Brasil}

Dissertação apresentada ao Programa de PósGraduação em Epidemiologia Experimental e Aplicada às Zoonoses da Faculdade de Medicina Veterinária e Zootecnia da Universidade de São Paulo para obtenção do título de Mestre em Medicina Veterinária

\section{Departamento:}

Medicina Veterinária Preventiva e Saúde Animal

Área de concentração:

Epidemiologia Experimental e Aplicada às Zoonoses

\section{Orientador:}

Prof. Dr. Marcelo Bahia Labruna

São Paulo 
Autorizo a reprodução parcial ou total desta obra, para fins acadêmicos, desde que citada a fonte.

DADOS INTERNACIONAIS DE CATALOGAÇÃO-NA-PUBLICAÇÃO

(Biblioteca Virginie Buff D’Ápice da Faculdade de Medicina Veterinária e Zootecnia da Universidade de São Paulo)

T.1744

Ataliba, Alexandre Camargo

Estudo de Borrelia spp. no Brasil / Ataliba, Alexandre Camargo. - São

Paulo: A. C. Ataliba, 2006.

$61 \mathrm{f}$ : : il.

Dissertação (mestrado) - Universidade de São Paulo. Faculdade de Medicina Veterinária e Zootecnia. Departamento de Medicina Veterinária Preventiva e Saúde Animal, 2006.

Programa de Pós-graduação: Epidemiologia Experimental e Aplicada às Zoonoses.

Área de concentração: Epidemiologia Experimental e Aplicada às Zoonoses.

Orientador: Prof. Dr. Marcelo Bahia Labruna.

1. Doença de Lyme-Símili. 2. Borrelia. 3. Amblyomma cajennense. 4. Espiroquetose aviária. 5. Borrelia anserina.. I. Título. 


\section{UNIVERSIDADE DE SÃO PAULO \\ Faculdade de Medicina Veterinária e Zootecnia}

Cidade Universitária "Armando de Salles Oliveira"

Comissão de Bioética

\section{CERTIFICADO}

Certificamos que o Projeto intitulado "Investigação da presença de Borrelia sp. Em carrapatos Amblyomma cajennense em áreas do Estado de São Paulo com ocorrência de casos humanos de doença de Lyme-Símile", protocolo n624/2005 (não utilizando animais de laboratório, serão utilizados carrapatos), sob a responsabilidade do Prof. Dr. Marcelo Bahia Labruna, está de acordo com os princípios éticos de experimentação animal da Comissão de Bioética da Faculdade de Medicina Veterinária e Zootecnia da Universidade de São Paulo e foi aprovado "ad referendun".

(We certify that the Research "Investigation of the presence of Borrelia sp. in Amblyomma cajannense ticks in areas from São Paulo State, Brazil, with reported cases of Lyme-Like disease in humans", protocol number 624/2005, under the responsibility of Prof. Dr. Marcelo Bahia Labruna, agree with Ethical Principles in Animal Research adopted by Bioethic Commission of the Faculty of Veterinary Medicine and Zootechny of University of São Paulo and was approved "ad referendun", meeting).

São Paulo, 11 de março de 2005

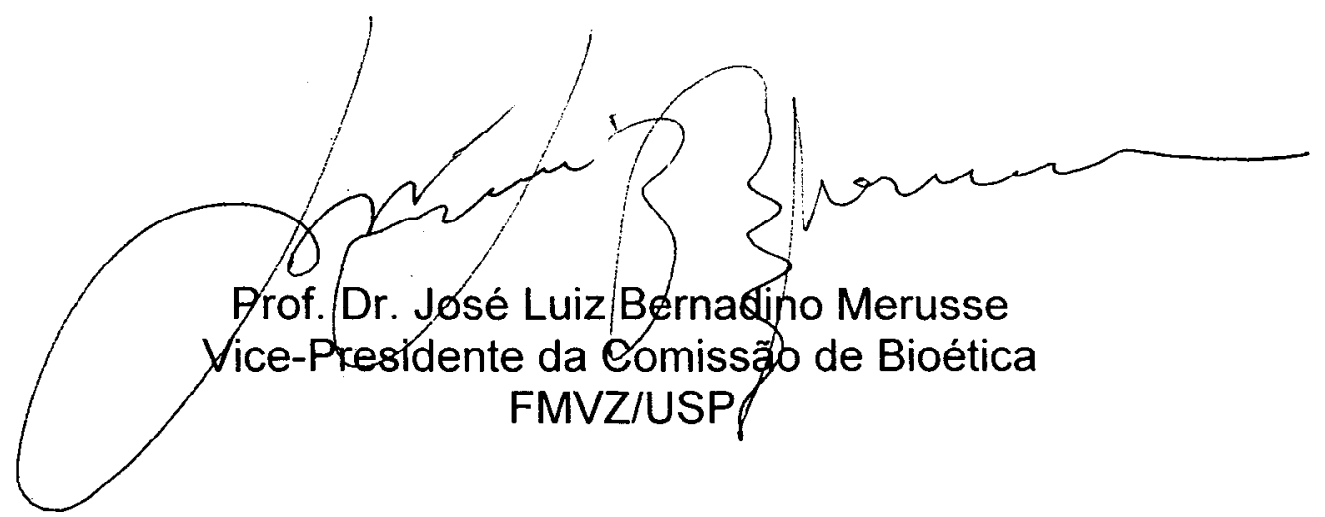

Av. Prof. Dr. Orlando Marques de Paiva, 87 - 05508-000 - Cid. Univ. "Armando de Salles Oliveira" Fones: (011) 3091-7671/3091-7676 Fax: (011) 3032-2224 


\section{FOLHA DE AVALIAÇÃO}

Nome: ATALIBA, Alexandre Camargo

Título: Estudo de Borrelia spp. no Brasil

Data:

Dissertação apresentada ao Programa de PósGraduação em Epidemiologia Experimental e Aplicada às Zoonoses da Faculdade de Medicina Veterinária e Zootecnia da Universidade de São Paulo para obtenção do título de Doutor em Medicina Veterinária

Banca examinadora:

Prof. Dr.

Instituição:

Assinatura:

Julgamento:

Prof. Dr.

Instituição:

Assinatura:

Julgamento:

Prof. Dr.

Instituição:

Assinatura: Julgamento: 
Dedicado a minha família :

Marly e José Ataliba, Fernanda e Camila pelos ensinamentos, amor, apoio e confiança em todos os momentos da minha vida pessoal e profissional; aos meus avós Tida e Zico e minha Tia Márcia, sempre presentes em minha vida. 


\section{AGRADECIMENTOS}

- Agradeço primordialmente a Deus pelas bênçãos derramadas durante toda a minha vida.

Gostaria de agradecer também as pessoas que de alguma maneira estiveram presentes, fisicamente ou não, comigo durante a produção desse trabalho e que foram essenciais tanto na formação profissional como na pessoal. São eles:

- Meus pais, pela educação ministrada e todo o esforço (que não foi pouco) para a minha formação acadêmica;

- Minhas irmãs Fernanda e Camila que sempre me cobriram de beijos;

- Meus avós e minha tia Márcia;

- Adriana Rosa, minha namorada pelo amor e amizade;

- Meu orientador Prof ${ }^{\mathrm{o}}$ Marcelo Bahia Labruna;

- FAPESP pelo apoio financeiro;

- Meu grande amigo e irmão Rafael que durante o percurso desse trabalho me auxiliou na minha residência em São Paulo;

- Os "parças do laboratório dos Carrapatos", Pinter, Richard, Ricardo, Mauricião, Daniel e Iara, pela convivência harmoniosa em grupo, risos e discussões proveitosas para o enriquecimento do trabalho;

- A todos integrantes dos laboratórios de doenças parasitárias;

- Adriana, Mikaela, Sheila e Lara;

- Danival, Virgínia e Cristina; 
- Marcelo (Wilinha), Tiaguinho, Jonas e Simone, pela ajuda nas coletas e processamento do material;

- Professores Rodrigo Martins e Paulo Brandão pela ajuda no desenvolvimento das análises molecular;

- Professores Leonardo, Sonia e Sílvio;

- Professores Odilon e Marilda Vidotto, por me iniciarem na minha vida científica;

- Prof. o José Sergio da UFMG pela amostra de B. anserina cedida;

- Prof $^{\mathrm{o}}$ Natalino Yoshinari e a todos do laboratório LIM 17, Virgínia, Elenice e Mariana;

- Minha grande amiga Flora Kano;

- Eliane que com muita simpatia e paciência me ajudou muito, principalmente, no manejo com os animais do biotério;

- Taís e Maria (polonesa), pela paciência e ajuda no manejo com os animais do biotério;

- A todos que de alguma maneira me ajudar na produção desse estudo e/ou estiveram presente comigo durante o mesmo;

- Integrantes da Republica Mulheres S/A (Londrina-PR), pelos cuidados e carinho com as minhas "filhas caninas";

- E por último, mas não menos importante: as minhas amadas "filhas caninas", Bruna e Cubinha, que mesmo quando longe sempre festejavam a minha chegada, além da alegria que me proporcionam. 


\section{RESUMO}

ATALIBA, A. C. Estudo de Borrelia spp. no Brasil. [Study of Borrelia spp. in Brazil]. 2006. 61 f. Dissertação (Mestrado em Medicina Veterinária) - Faculdade de Medicina Veterinária e Zootecnia, Universidade de São Paulo, São Paulo, 2006.

A doença de Lyme é uma doença causada pelas bactérias do complexo Borrelia burgdorferi sensu lato que são transmitidas por carrapatos do complexo Ixodes ricinus. A distribuição geográfica dessas bactérias é confirmada no Hemisfério Norte (America do Norte, Europa e Ásia). Suspeita-se que uma enfermidade, compatível com doença de Lyme no Brasil, esteja provavelmente relacionada a uma espécie de Borrelia diferente das espécies causadoras de doença de Lyme no hemisfério Norte e que o vetor sejam carrapatos do gênero Amblyomma. Por estas razões, a doença brasileira passou a ser chamada de Doença de Lyme-Símile (DLS). A borreliose aviária é causada pela Borrelia anserina, que apresenta distribuição cosmopolita. É transmitida por carrapatos argasideos do gênero Argas. O presente trabalho foi dividido em dois capítulos: o primeiro investigou a presença de Borrelia spp em áreas onde foram relatados casos humanos de DLS no Estado de São Paulo. No segundo capítulo, é relatado o primeiro isolamento em meio BSK e a caracterização molecular de uma cepa de espiroqueta aviária presumidamente identificada como B. anserina, no Brasil. Para o primeiro capítulo, foram processados um total de 349 carrapatos Amblyomm cajennense adultos coletados em áreas com suspeita de DLS, nove amostras de sangue ou tecidos de pacientes humanos com diagnóstico clínico e sorológico de DLS, duas amostras de caldas de meio BSK previamente inoculado com tecidos ou sangue de pacientes com suspeita de DLS, e três amostras de caldas de meio BSK previamente inoculado com carrapatos coletados de áreas com suspeita de DLS. Essas amostras tiveram seu DNA extraído e testado pela nested-PCR com primers específicos para porções do gene flagelina B (flaB), aptos a amplificar porções deste gene de qualquer espécie de Borrelia. Todas as amostras foram negativas pela nested-PCR, não evidenciando a presença de Borrelia sp nas amostras avaliadas. Para o segundo capítulo, foi utilizada uma amostra de espiroqueta aviária originária de carrapatos Argas miniatus, colhidos em um galinheiro no Município de Pedro Leopoldo, MG. O isolamento in vitro e caracterização molecular da espiroqueta aviária foi feito a partir da inoculação de soro infectado, contendo espiroquetas viáveis, em meio BSK. O soro, baço, fígado e o próprio cultivo foram utilizado para amplificação na PCR para os genes $r r s$ e flaB, seguido de seqüenciamento dos mesmos. $\mathrm{O}$ isolamento da espiroqueta foi obtido com sucesso, com várias passagens realizadas. A 
análise genética das seqüências do isolado mostrou 99.8\% (483 de 484-bp) e 98.7\% (754 de 764-bp) de similaridade às seqüências correspondentes dos genes rrs e flaB de B. anserina, respectivamente, disponíveis no GenBank. Pela análise filogenética inferida pela seqüência parcial do gene $f l a B$, a cepa Brasileira agrupou-se com a seqüência de $B$. anserina dos EUA. Os resultados indicam a cepa brasileira estudada, designada de cepa PL, pertence à espécie $B$. anserina.

Palavras-chave: Doença de Lyme-Símili. Borrelia. Amblyomma cajennense. Espiroquetose aviária. Borrelia anserina. 


\begin{abstract}
ATALIBA, A. C. Study of Borrelia spp. in Brazil. [Estudo de Borrelia spp. no Brasil]. 2006. 61 f. Dissertação (Mestrado em Medicina Veterinária). - Faculdade de Medicina Veterinária e Zootecnia, Universidade de São Paulo, São Paulo, 2006.
\end{abstract}

Lyme disease is caused by bacteria belonging to the complex Borrelia burgdorferi sensu lato, which are transmitted by ticks of the Ixodes ricinus complex. The distribution of these bacteria are restricted to the northern hemisphere (North America, Europe, and Asia). Lyme disease-like cases have been reported in Brazil, but it is possible that another Borrelia species is involved in these cases, and ticks of the genus Amblyomma have been implicated as vectors. Due to these reasons, the disease in Brazil has been referred as Lyme Disease-Simile (LDS). Borrelia anserina, the agent of avian spirochetosis, has a wordwide distribution, where it is transmitted primarily by ticks of the genus Argas. The present study was divided in two chapters: the first one evaluated the presence of Borrelia spp in areas of the state of São Paulo where LDS have been reported. The second chapter reports the first in vitro isolation in BSK medium and molecular characterization of a spirochete strain from Brazil, presumably identified as B. anserina. For the first chapter, a total of 349 adult ticks (Amblyomma cajennense) collected in areas where LDS cases have been reported were processed. In addition, nine human blood or tissue samples from patients with clinical and serological diagnostic of LDS, two samples from BSK medium previously inoculated with samples of skin or blood of LDS patients, and three samples of BSK medium previously inoculated with tick samples were also processed. All these samples were processed for DNA extraction and then tested by nested-PCR employing primers targeting a portion of the flagelin B gene (flaB), which amplify a flaB fragment in all known Borrelia species. All samples were negative by this nested-PCR, showing no evidence of Borrelia sp in the tested samples. The second chapter evaluated an avian spirochete strain originated from Argas miniatus ticks from Pedro Leopoldo municipality, state of Minas Gerais. DNA fragments of the rrs (16S rRNA) and flab genes were amplified by PCR and sequenced to determine phylogenetic similarities. The resulting sequences were $99.8 \%$ (483 of 484) and 98.7\% (754 of 764) similar to GenBank corresponding sequences of $B$. anserina rrs and flaB genes, respectively. By neighbor-joining phylogenetic analysis, the $f l a B$ sequence of the Brazilian strain clustered in a monophyletic group with the sequence of $B$. anserina under $100 \%$ bootstrap support. The isolate was successfully isolated in BSK medium, with seven passages performed. The spirochete crude 
antigen, fixed in glass slides, showed strong immunfluorescence reactivity with sera from chickens previously inoculated with the isolate. The spirochete strain isolated in the present study was genetically identified as B. anserina, labeled as strain PL.

Key words: Lyme disease-Simili. Borrelia. Amblyomma cajennense. Avian spirochetosis. Borrelia anserine. 
Capítulo I - Investigação da presença de Borrelia sp. em carrapatos de áreas do Estado de São Paulo com ocorrência de casos humanos de doença de Lyme-Símile (DLS) e em amostras de humanos com casos clínicos de DLS

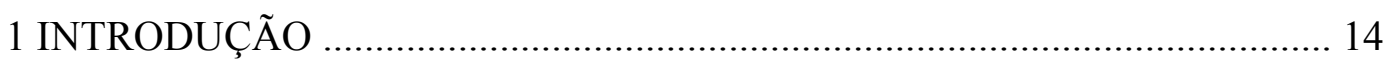

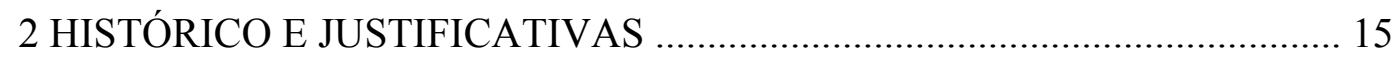

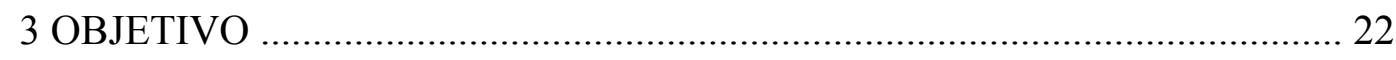

4 MATERIAIS E MÉTODOS …................................................................ 23

4.1 ÁREA DO ESTUdO E OBTENÇÃO DE CARRAPATOS ……………………………...... 23

4.2 OBTENÇÃO DAS AMOSTRAS DE HUMANOS E DE CULTIVOS ………......................... 25

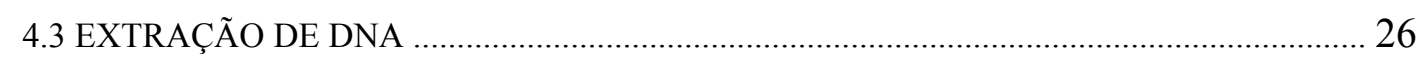

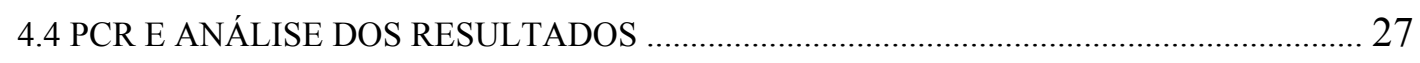

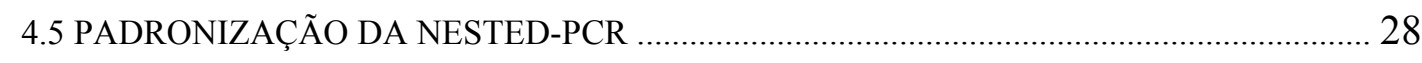

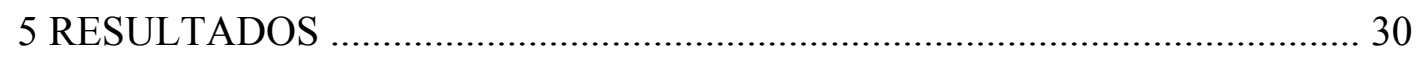

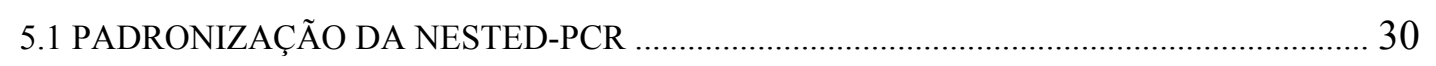

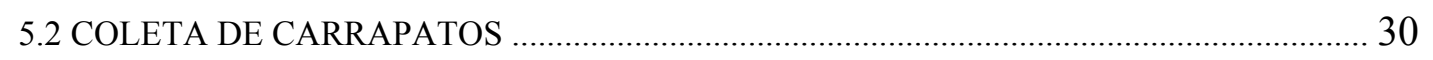

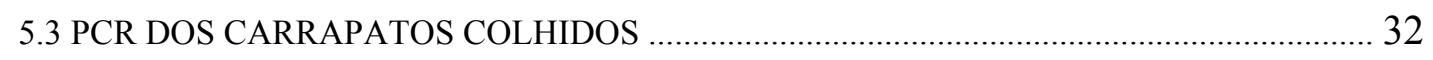

5.4 AMOSTRAS DE PACIENTES E DE CULTIVOS ............................................................... 32

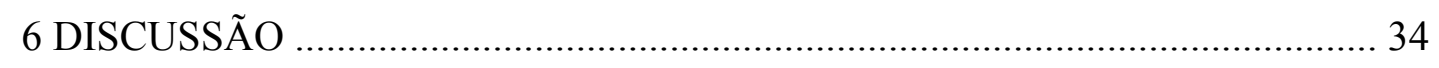

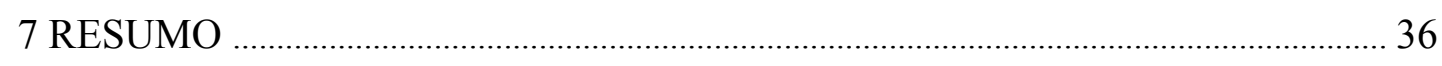


Capítulo II - Caracterização Molecular e Isolamento em meio de cultura (BSK) de uma cepa de Borrelia anserina de Pedro Leopoldo, MG

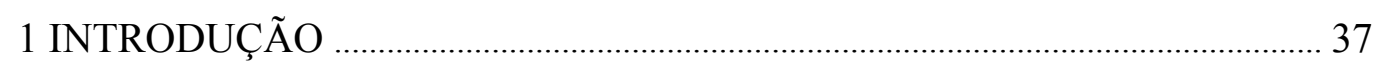

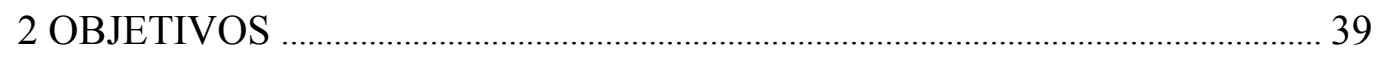

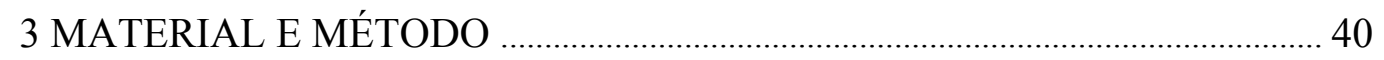

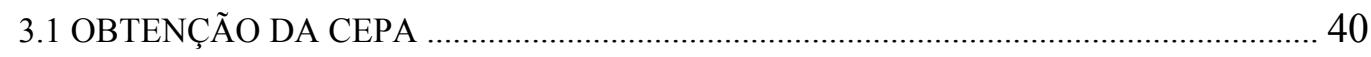

3.2 MANUTENÇÃO DA CEPA E OBTENÇÃO DE MATERIAL PARA ANÁLISE

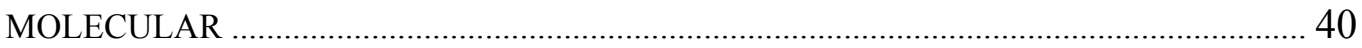

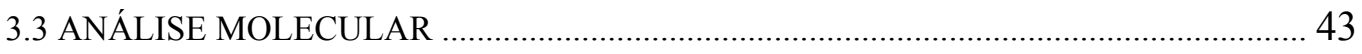

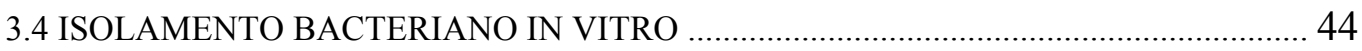

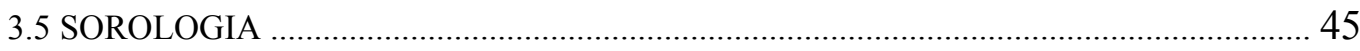

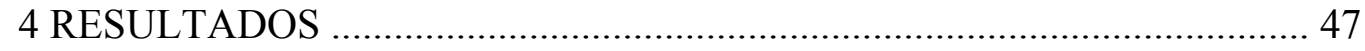

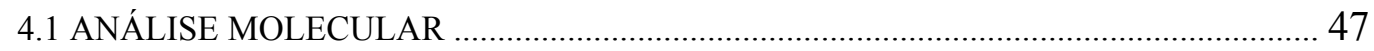

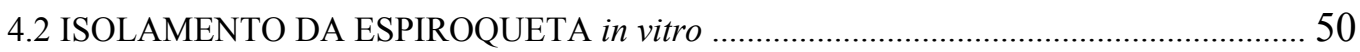

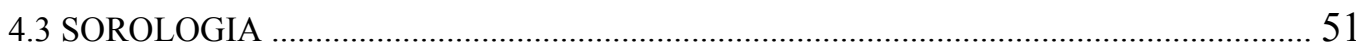

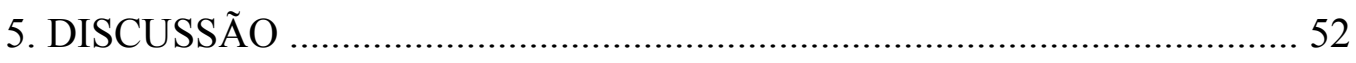

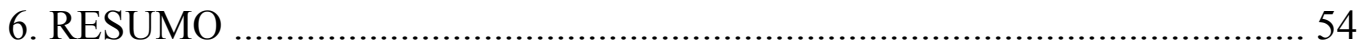

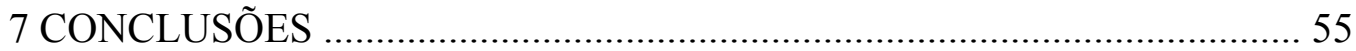

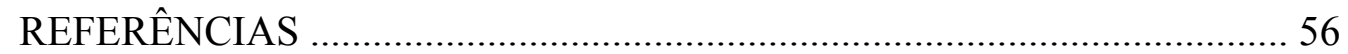




\section{Estudo de Borrelia spp. no Brasil.}

Este estudo foi dividido em dois capítulos, conforme descritos a seguir:

Capítulo I: Investigação da presença de Borrelia sp. em carrapatos de áreas do Estado de São Paulo com ocorrência de casos humanos de doença de Lyme-Símile (DLS) e em amostras de humanos com casos clínicos de DLS

Capítulo II: Caracterização Molecular e Isolamento em meio de cultura (BSK) de uma cepa de Borrelia anserina de Pedro Leopoldo, MG. 


\section{CAPÍTULO I}

\section{Investigação da presença de Borrelia sp. em carrapatos de áreas do Estado de São Paulo com ocorrência de casos humanos de doença de Lyme-Símile (DLS) e em amostras de humanos com casos clínicos de DLS}

\section{INTRODUÇÃO}

No início da década de 1990, foi formado o grupo de pesquisa em Doença de Lyme no Brasil, envolvendo pesquisadores dos Estados de São Paulo, Rio de Janeiro e Mato Grosso do Sul, para investigar a ocorrência e epidemiologia desta doença no Brasil (YOSHINARI et al., 1992). Desde então, vários trabalhos foram realizados, chegando-se a uma seguinte conclusão geral: no Brasil, há casos humanos de doença com características clínicas semelhante à doença de Lyme, porém de etiologia diferente, muito provavelmente causada por uma espécie de Borrelia diferente das espécies integrantes ao complexo Borrelia burgdorferi sensu lato. Há evidências epidemiológicas para que esta doença seja transmitida para humanos através do parasitismo de carrapatos do gênero Amblyomma. A doença brasileira passou a ser chamada de Doença de Lyme-Símile (DLS) (YOSHINARI et al., 2003).

Visando dar continuidade aos estudos da etiologia e epidemiologia da DLS, o presente projeto foi desenvolvido baseado em conhecimentos adquiridos nestes estudos prévios no Brasil, e também em recentes estudos conduzidos no sul dos Estados Unidos, onde uma nova borreliose clínica, transmitida por carrapatos do gênero Amblyomma, vem sendo investigada. Fatores ecológicos sugerem que a borreliose do sul dos Estados Unidos seja mais próxima da DLS no Brasil, do que a própria doença de Lyme. 


\section{HISTÓRICO E JUSTIFICATIVAS}

A doença de Lyme é uma enfermidade causada por bactérias espiroquetas do complexo Borrelia burgdorferi sensu lato, o qual é composto por pelo menos 11 espécies taxonomicamente reconhecidas. Destas, as espécies Borrelia burgdorferi sensu stricto, Borrelia garinii, e Borrelia afzelli são as de maior patogenicidade, estando associadas às diferentes manifestações clínicas da doença de Lyme em humanos e animais domésticos. As demais espécies deste complexo (Borrelia andersonii, Borrelia bissettii, Borrelia valaisiana, Borrelia lusitaniae, Borrelia japonica, Borrelia tanukii, Borrelia turdae e Borrelia sinica) são consideradas minimamente patogênicas ou não patogênicas para humanos (STEERE; COBURN; GLICKSTEIN, 2004). Todas estas 11 espécies que compõe o complexo $B$. burgdorferi sensu lato apresentam em comum o fato de terem sido relatadas exclusivamente em regiões temperadas do hemisfério Norte, onde estão associadas na natureza com carrapatos do complexo Ixodes ricinus. Dentro deste complexo, destacam-se as espécies I. ricinus e Ixodes persulcatus na Europa e Ásia, e Ixodes scapularis e Ixodes pacificus na América do Norte (STEERE; COBURN; GLICKSTEIN, 2004).

Embora quadros clínicos compatíveis com a doença de Lyme tenham sido relatados em humanos da Europa desde o final do século 19, a descoberta do agente etiológico e a comprovação de sua transmissão por carrapatos só foram evidenciados no início da década de 1980 (WEBER, 2001). A partir daí, as pesquisas nos campos da epidemiologia, patologia e imunologia da doença tiveram um incremento gigantesco na década de 1990, a ponto da bactéria $B$. burgdorferi ser considerado um dos agentes bacterianos mais investigados no mundo durante esta década (STEERE; COBURN; GLICKSTEIN, 2004). Obviamente, tal 
investigação em massa proporcionou enormes descobertas em todos os campos da doença, e também a descoberta de outros agentes patogênicos associados a carrapatos, mas que não integram o complexo B. burgdorferi sensu lato. Como exemplo, foi a descoberta da espécie Borrelia lonestari, que foi recentemente associada à doença em humanos no sul dos Estados Unidos, sendo uma bactéria distinta das outras espécies de Borrelia, não sendo integrante do complexo B. burgdorferi sensu lato (JAMES et al., 2001). Além disso, B. lonestari tem sido associada exclusivamente a carrapatos do gênero Amblyomma, principalmente a espécie $A$. americanum no sul dos Estados Unidos (STROMDAHL et al., 2003), e mais recentemente, com a espécie Amblyomma cajennense na região fronteiriça do México com os Estados Unidos (P. Williamson, comunicação pessoal). A doença causada em humanos pela bactéria B. lonestari tem sido chamada de "STARI (southern tick-associated rash illness)", sendo clinicamente semelhante à doença de Lyme, especialmente nas manifestações cutâneas (JAMES et al., 2001; STROMDAHL et al., 2003).

No Brasil, vários casos humanos diagnosticados como doença de Lyme têm sido relatados a partir do final da década de 1980 nos estados do Rio de Janeiro, São Paulo, Mato Grosso do Sul e Amazonas (AZULAY et al., 1991; COSTA et al., 1996; FILGUEIRA; TROPPE; GONTIJO FILHO, 1989; TALHARI; SCHETTINI; PARREIRA, 1987; YOSHINARI et al., 1993). Todos esses casos foram diagnosticados através de provas sorológicas (ELISA e Western blotting) empregando-se antígenos de B. burgdorferi sensu stricto. Como são conhecidas reações sorológicas cruzadas entre diferentes espécies de Borrelia, mesmo entre espécies filogeneticamente mais distantes (BENNETT, 1995), não foi possível afirmar que esses casos humanos da doença no Brasil foram desencadeados por um agente pertencente ao complexo B. burgforgeri sensu lato, já que essas provas sorológicas têm mostrado padrões de reações distintos daqueles observados nas áreas endêmicas para doença de Lyme no hemisfério Norte (YOSHINARI et al., 2000). Tal fato, associado a diversas 
tentativas infrutíferas de isolar ou identificar o agente em seres humanos doentes, animais silvestres e carrapatos, levou os pesquisadores a adotar o nome de "doença de Lyme-Símile" (DLS) para esta nova enfermidade que vem sendo diagnosticada no Brasil (YOSHINARI et al., 2003).

No final da década de 1990, pesquisadores dos Estados de São Paulo e Mato Grosso do Sul iniciaram uma série de pesquisas epidemiológicas, com o propósito de encontrar o agente etiológico da DLS (BARROS-BATTESTI, 1998; ABEL et al., 2000; COSTA; BONOLDI; YOSHINARI, 2002). Para tal, seguindo-se o modelo da doença de Lyme em regiões temperadas do hemisfério Norte, os estudos no estado de São Paulo foram direcionados para carrapatos do gênero Ixodes (ABEL et al., 2000; BARROS-BATTESTI, 1998). Como foi constatado que a espécie Ixodes loricatus, parasita de gambás e pequenos roedores, era a espécie mais abundante deste gênero na região Sudeste, estando também presente nas áreas desta região onde foram diagnosticados os casos de DLS, pelo menos dois grandes estudos tentaram identificar o agente, através de PCR, ou isolar o agente em meio de cultura BSK (meio ideal para o isolamento de B. burgdorferi sensu lato), através do processamento de carrapatos I. loricatus colhidos de animais silvestres nestas áreas (BARROS-BATTESTI, 1998; ABEL et al., 2000). Muito embora achados iniciais sugeriram resultados promissores no isolamento de espiroquetídeos em sangue de gambás, roedores ou carrapatos, um estudo posterior analisou parte destes isolados, através de PCR, imunofluorescência indireta e microscopia eletrônica, chegando-se a conclusão de que o que havia sido antes considerado como espiroquetas (através de microscopia óptica de campo escuro), eram na verdade estruturas compostas por agrupamentos de flagelos destacados de outras bactérias contaminantes presentes no meio de cultura (MARZAGÃO, 2001). Tal descoberta permitiu-nos concluir que o agente etiológico da DLS no Brasil era diferente das espiroquetas integrantes do complexo Borrelia burgdorferi sensu lato. 
Analisando-se a epidemiologia da doença de Lyme no hemisfério Norte (BENNETT, 1995), pode-se constatar que no Brasil não há uma condição epidemiológica favorável ao estabelecimento do agente. No hemisfério Norte, bactérias do complexo B. burdorferi sensu lato são transmitidas por espécies de carrapatos do complexo I. ricinus. Tal complexo é representado no Brasil por apenas uma espécie de carrapato, Ixodes aragaoi, a qual é uma espécie com populações bastante escassas, sendo muito raramente encontrada em levantamentos acarológicos (GUIMARÃES; TUCCI; BARROS-BATTESTI, 2001). Tal raridade está seguramente relacionado à ausência de parasitismo humano por I. aragaoi no Brasil. Além disso, as condições climáticas da região temperada do hemisfério Norte são essenciais para a manutenção do agente na natureza, pois uma vez que a transmissão transovariana de $B$. burgdorferi nos carrapatos é sem importância epidemiológica (BENNETT, 1995; PATRICAN, 1997), a bactéria é mantida na população de carrapatos graças ao clima temperado, que ao regular o ciclo do carrapato para uma duração mínima de dois anos, através de baixas temperaturas e indução à diapausa, garante que ninfas de uma geração posterior, infectadas por B. burgdorferi, se alimentem em um determinado hospedeiro semanas antes das larvas de uma geração anterior, garantindo assim a transmissão transestadial do agente entre diferentes gerações do carrapato (SCHWAN, 1996; STEERE; COBURN; GLICKSTEIN, 2004). Tal tipo de sincronia em populações de carrapatos nunca fora constatada em regiões de clima tropical ou subtropical (SONENSHINE, 1991).

Antes da descoberta de $B$. lonestari no sul dos Estados Unidos, havia uma grande dúvida quanto ao agente etiológico dos casos diagnosticados clinicamente como doença de Lyme nesta região. Tal dúvida era alimentada pelo fato da região não albergar populações estabelecidas de I. scapularis e I. pacificus, vetores da doença de Lyme em áreas mais setentrionais dos Estados Unidos (JAMES et al., 2001, STROMDAHL et al., 2003). Em contraste, o principal carrapato que infestava humanos nessas áreas era a espécie $A$. 
americanum, mas estudos laboratoriais mostraram a incapacidade vetorial deste carrapato em transmitir a B. burgdorferi (PIESMAN; SINSKY, 1988). Com a descoberta de B. lonestari em carrapatos A. americanum a partir do final da década de 1990 (BARBOUR et al., 1996), e os trabalhos subsequentes que confirmaram a patogenia deste agente para humanos (FELZ et al., 1999; JAMES et al., 2001), ficou evidenciado que no sul dos Estados Unidos existe um agente que, muito embora também seja do gênero Borrelia, apresenta características ecológicas bem distintas de B. burgdorferi sensu lato, embora ambos causem doenças com características clínicas semelhantes. Uma característica importante da B. lonestari é a possível significância biológica de sua transmissão transovariana entre gerações de carrapatos, fato que não se observa na ecologia de B. burdorferi (STROMDAHL et al., 2003).

Recentemente, o cultivo de $B$. lonestari foi estabelecido em laboratório pela primeira vez (VARELA et al., 2004). Este cultivo foi obtido em monocamadas de células de carrapato da linhagem ISE6 (células embrionárias de I. scapularis). Todas as tentativas de cultivo deste agente em meio BSK (meio acelular utilizado para o cultivo de B. burgdorferi), ou modificações deste, foram infrutíferas (VARELA et al., 2004). É interessante notar que todos os trabalhos Brasileiros que tentaram isolar o agente da DLS utilizaram-se meio BSK. Sendo assim, se existe a $B$. lonestari no Brasil, os resultados negativos obtidos no Brasil passam a ser compreensíveis.

Em um trabalho recente no Texas, EUA, foi encontrada a infecção pela espécie $B$. lonestari em carrapatos A. cajennense na área de fronteira do Texas (EUA) com o México (comunicação pessoal) ${ }^{1}$. Como A. cajennense tem sido identificado como a única espécie de carrapato parasitando humanos nas áreas onde têm sido relatados casos humanos de DLS (COSTA; BONOLDI; YOSHINARI, 2002; YOSHINARI et al., 2000), é possível que este carrapato tenha sido o vetor do agente etiológico da doença. Inclusive, alguns dos casos diagnosticados de DLS foram relatados com histórico recente de parasitismo por formas 
imaturas de Amblyomma sp. (YOSHINARI et al., 1999, 2000), muito provavelmente da espécie $A$. cajennense.

A experiência dos Estados Unidos mostrou que o método de PCR simples utilizando primers para uma porção do gene flagelina B (flaB), especifico para o gênero Borrelia, sem uma segunda reação de amplificação, não é suficiente para visualizar a presença de bandas amplificadas de B. lonestari em géis de agarose convencionais corados por brometo de etídeo, a partir de carrapatos do gênero Amblyomma (Comunicação pessoal) ${ }^{1}$. Tal fato está possivelmente relacionado à baixa concentração da espiroqueta nos tecidos dos carrapatos $(\text { No prelo })^{2}$. É interessante notar que nenhum dos trabalhos que buscou a detecção de Borrelia sp em carrapatos no Brasil utilizou-se o método de nested-PCR, embora todos utilizaram primers para o gene flaB. Um desses trabalhos (GEHRKE, 2002), que avaliou diversas espécies de carrapatos do gênero Amblyomma de Rondônia para a presença de Borrelia sp, obteve todos carrapatos negativos pelo PCR simples convencional, com visualização dos produtos em gel de agarose corado por brometo de etídeo. No entanto, quando estes produtos foram submetidos ao método de southern blotting (método considerado de sensibilidade similar ao nested-PCR para visualização de produtos amplificados), 9 de um total de 158 lotes de carrapatos, englobando cinco espécies de Amblyomma, foram positivos para Borrelia sp. Tal fato reforça achados anteriores de que a técnica de PCR simples, interpretada em gel de agarose, não é sensível suficiente para detectar DNA de Borrelia sp em carrapatos do gênero Amblyomma.,

Sendo assim, o presente trabalho objetivou investigar a presença de B. lonestari, ou algum agente similar (Borrelia spp), em carrapatos $A$. cajennense provenientes de áreas onde foram relatados casos humanos de DLS no Estado de São Paulo. Para tal investigação, foi

\footnotetext{
${ }^{1}$ Informação fornecida por STROMDAHL et al., 2003

${ }^{2}$ WILLIAMSON, P. C.; DOBBS, N. A. Detection of Borrelia lonestari by Quantitative Real-Time PCR. Journal Clinical Microbiology, 2004.
} 
utilizado um método de nested-PCR com primers para porções do gene $f l a B$, considerado recentemente um método com sensibilidade para um mínimo de 10 cópias do gene alvo no material a ser testado por reação (WILLIAMSON; DOBBS, 2004). 


\section{OBJETIVO}

O objetivo do presente projeto foi investigar a presença de DNA de Borrelia spp em carrapatos $A$. cajennense provenientes de áreas de ocorrência de casos humanos de doença de Lyme-Símile (DLS) no Estado de São Paulo e de amostras de humanos com diagnóstico clínico de DLS e carrapatos provenientes do Laboratório de Investigação em Reumatologia, Hospital das Clínicas, Faculdade de Medicina, Universidade de São Paulo (LIM-17). 


\section{MATERIAL E MÉTODOS}

Para a investigação do agente causador da DLS foi feita a colheita de carrapatos de vida livre em áreas onde houve casos suspeitos da doença (diagnóstico clínico). Além dos carrapatos colhidos, amostras de pacientes do Hospital das Clínicas (sangue e fragmentos de pele) e de caldas de cultivo in vitro inoculado com tecidos ou sangue de pacientes e carrapatos coletados de áreas com suspeita de DLS também foram analisadas.

\section{1 ÁREA DO ESTUDO E OBTENÇÃO DE CARRAPATOS}

Carrapatos da espécie $A$. cajennense foram obtidos em vida livre ou em parasitismo sobre eqüinos, em três áreas incriminadas como foco de transmissão da DLS, conforme descrito abaixo. Todos os diagnósticos desses casos clínicos foram realizados no Laboratório de Investigação em Reumatologia, Hospital das Clínicas, Faculdade de Medicina, Universidade de São Paulo (LIM-17). Estas três áreas de foco apresentam em comum a presença de eqüinos e uma grande quantidade de carrapatos da espécie $A$. cajennense, sendo descritas a seguir.

-Área 1. Condomínio Vale Verde, Município de Itapevi, SP. Desta área foram obtidos os primeiros dois casos de DLS no Brasil, em dois irmãos que foram infestados por carrapatos nesta área no ano de 1992 (YOSHINARI et al., 1993).

-Área 2. Área sub-urbana (Bairro Rodeio) de Mogi das Cruzes, SP. Trata-se de uma área na periferia da cidade, com criação de eqüinos de trabalho. No ano de 2004, foi diagnosticado 
um caso clínico de DLS em um residente do local, após ser infestado pelo carrapato $A$. cajennense (Comunicação pessoal) $)^{3}$.

-Área 3. Condomínio Praias Paulistanas. Neste condomínio, ás margens da represa de Guarapiranga, zona sul do Município de São Paulo, SP, foi recentemente diagnosticado, em novembro de 2003, um caso clínico de DLS em uma criança residente no local (comunicação pessoal) ${ }^{4}$. Foi realizada uma vistoria no local, juntamente com técnicos do escritório regional Superintendência de Controle de Endemias do Estado de São Paulo (SUCEN), sendo constatada uma superpopulação de $A$. cajennense no ambiente, inclusive no peridomicílio da residência da criança acometida.

Em cada uma destas três áreas, carrapatos $A$. cajennense adultos foram colhidos em vida livre (através de armadilhas de $\mathrm{CO}_{2}$ ) ou em parasitismo sobre os eqüinos, no período de Janeiro a fevereiro de 2005, época do ano de maior ocorrência do estágio adulto deste carrapato no Estado de São Paulo (LABRUNA et al., 2002). Optou-se por examinar apenas indivíduos adultos, pois este estágio de vida é o único para o qual existem chaves taxonômicas para identificação de espécies do gênero Amblyomma no Brasil, além de ser o estágio que teoricamente apresenta mais chances de se infectar pelo agente dentro de seu ciclo de vida, ou seja, durante os estágios anteriores, de ovo (transmissão transovariana) e nas alimentações larval e ninfal. Os carrapatos foram trazidos vivos para o laboratório e estocados $\mathrm{a}-80^{\circ} \mathrm{C}$ até análise, descrita abaixo.

\footnotetext{
${ }^{3}$ Informaçao fornecida pela Secretaria de Saúde da Prefeitura Municipal de Mogi das Cruzes

${ }^{4}$ Informação fornecida pela SUCEN em 2003
} 
Inicialmente, o número mínimo de carrapatos a ser colhido e examinado por área foi de 114 indivíduos adultos. Este número foi calculado através do programa Epi-Info (versão 6), considerando uma prevalência estimada de 5\% de carrapatos infectados na população [dados extraídos em levantamentos da infecção por B. lonestari em carrapatos A. americanum nos EUA (STROMDAHL et al., 2003)], erro de 4\% e intervalo de confiança de 95\%. Portanto, considerando-se as três áreas do presente estudo, estimou-se um número total mínimo de 342 carrapatos adultos.

\subsection{OBTENÇÃO DAS AMOSTRAS DE HUMANOS E DE CULTIVOS}

Amostras oriundas de pacientes do Hospital das Clínicas (sangue e fragmentos de pele) e de caldas de cultivo in vitro inoculado com tecidos ou sangue de pacientes suspeitos e carrapatos coletados de áreas com suspeita de DLS, foram analisadas sob a mesma metodologia que os carrapatos coletados. Todos esses pacientes foram diagnosticados com Doença de Lyme-símile pela clínica, epidemiologia e sorologia (Comunicação pessoal) ${ }^{5}$. Uma ninfa de Amblyomma sp foi colhida em parasitismos de um paciente do Hospital das Clinicas, tido como suspeito de portar DLS. Conforme a freqüência de pacientes suspeito de DLS que chegavam ao LIM-17, as amostras eram enviadas para investigação molecular de Borrelia sp.

\footnotetext{
${ }^{5}$ Informação fornecida por Natalino Yoshinari em 2004.
} 


\subsection{EXTRAÇÃO DE DNA}

A extração do DNA dos carrapatos foi realizada conforme adaptação do protocolo descrito por Chomkzynski (1993). Cada carrapato foi triturado individualmente em um microtubo de $1,5 \mathrm{ml}$, com o auxílio de um micropistilo. Neste tubo, adicionou-se tampão TE (10 mM TRIS HCl; 1 mM EDTA, pH 8,0) e água para completar um volume total de $150 \mu \mathrm{l}$ e $450 \mu 1$ de isotiocianato de guanidina, seguindo-se de homogeneização. À mistura, foram acrescentados $100 \mu \mathrm{l}$ de clorofórmio, submetendo-a à centrifugação (12.000 g, 5 minutos). A fase aquosa foi retirada e colocada em um novo microtubo estéril onde foi adicionado $400 \mu 1$ de propanol, seguido de um descanso mínimo de 2 horas à $-20^{\circ} \mathrm{C}$. Em seguida, a amostra foi centrifugada (12.000 g, 15 minutos), resuspendendo-se o sedimento em $800 \mu$ l de etanol 70\%, o qual foi novamente centrifugado (12.000 g, 15 minutos). O sedimento final foi resuspendido em $30 \mu 1$ de TE e o tubo colocado à $56^{\circ} \mathrm{C}$ por 15 minutos para facilitar a dissolução do DNA previamente precipitado. O material extraído final, com volume de $30 \mu 1$, foi congelado a $-20^{\circ}$ C até análise pela reação em cadeia da polimerase (PCR).

O DNA das amostras dos pacientes e dos cultivos foram extraídos utilizando-se o kit comercial DNAeasy Tissue Kit (marca Qiagen), conforme recomendação do fabricante. No total, foram analisadas seis amostras de sangue de pacientes, duas amostras de cultivo BSK inoculado com sangue de paciente e duas amostras de biopsia de pele de um mesmo paciente, sendo uma do cotovelo e uma das costas, onde havia lesões compatíveis com eritema migratório. Como controle positivo, utilizou-se DNA extraído de sangue humano "batizado" com B. burgdorferi oriunda de cultivo invitro.

Para a extração do DNA da ninfa, coletada em parasitismo no paciente humano, utilizou-se o mesmo protocolo que da extração dos carrapatos colhidos em vida livre. 


\subsection{PCR E ANÁLISE DOS RESULTADOS}

A metodologia de PCR deste trabalho foi a mesma utilizada para detecção de carrapatos naturalmente infectados por B. lonestari descrita por Barbour et. al. (1996). O DNA extraído de cada amostra (carrapato, amostra de pacientes e cultivo) foi analisado individualmente pela nested-PCR com primers direcionados para amplificação de porções do gene flagelina $B(f l a B)$ presente em bactérias do gênero Borrelia, conforme protocolo descrito por Stromdahl et al. (2003). Para a reação primária, foram utilizados os primers FlaLL (5'ACATATTCAGATGCAGACAGAGGT-3') e FlaRL (5'GCAATCATAGCCATTGCAGATTGT-3') num volume final de $50 \mu$ l contendo $5 \mu \mathrm{l}$ da amostra de DNA da amostra, cada primer a $1.0 \mu \mathrm{M}$, Tris- $\mathrm{HCl}(10 \mathrm{mM}), \mathrm{MgCl}_{2}(1.5 \mathrm{mM})$, dNTP (1.25 mM) e TaqDNA polimerase (1.5 U). Para a reação nested, foram utilizados os primers FlaLS (5'-AACAGCTGAAGAGCTTGGAATG-3') e FlaRS (5'CTTTGATCACTTATCATTCTAATAGC-3') num volume final de $50 \mu$ l contendo $1 \mu 1$ do produto final da reação primária, mais os reagentes nas mesmas concentrações citados acima. Os ciclos de temperatura e tempo para ambas as reações (primária e nested) consistiram em uma desnaturação inicial por 3 minutos a $95^{\circ} \mathrm{C}$, seguida de 40 ciclos, cada um consistindo em uma desnaturação a $95^{\circ} \mathrm{C}$ por 1 minuto, anelamento a $55^{\circ} \mathrm{C}$ por 1 minuto, e extensão a $75^{\circ} \mathrm{C}$ por 1 minuto. Para cada 10 amostras testadas numa bateria de reações, foram também testados DNA de B. burgdorferi sensu stricto (controle positivo) e água (controle negativo). Como produto final do nested-PCR foi esperado uma banda de 330 nt a ser visualizada em gel de agarose a 1,5\%, corado por brometo de etídeo e visualizado à trans-iluminação pela ultra violeta. Cada etapa laboratorial (extração de DNA, preparo da solução de amplificação, adição do DNA teste nas soluções, e análise do material amplificado em gel) foi realizada em 
um ambiente fisicamente separado, utilizada unicamente para tal finalidade na rotina do laboratório.

Se fragmentos amplificados fossem visualizados, de tamanho compatível com o esperado (330-bp), estes seriam purificados utilizando-se o produto comercial ExoSAP-IT (USB Corporation) e submetidos ao sequenciamento genético utilizando-se o "kit" comercial BigDye TM Terminator - Cycle Sequencing Ready Reaction - Applied Biosystems, em um seqüenciador de DNA modelo ABI Prism 310 Genetic Analyser (Applied Biosystens/Perkin Elmer), segundo seu manual de instruções. As seqüências obtidas seriam editadas pelo pacote de programas Bioedit ${ }^{\circledR}$ (HALL, 1999) e submetidas à análise de similaridade com as seqüências disponíveis no GenBank, através do programa BLAST analysis (ALTSCHUL et al., 1990).

As freqüências de carrapatos positivos, comprovadas pelo sequenciamento genético, serão comparadas com outras freqüências obtidas em trabalhos com carrapatos $A$. americanum e A. cajennense nos Estados Unidos.

\subsection{PADRONIZAÇÃO DA NESTED-PCR}

A padronização da Nested-PCR foi feita com a amostra B29 de Borrelia burgdorferi, gentilmente cedida pela Prof ${ }^{a}$. Sônia Pinheiro, do Laboratório de Zoonoses Bacterianas da FMVZ/USP. Para validação do protocolo de extração de DNA utilizado, e com o objetivo de verificar se o DNA do carrapato teria efeito inibidor na PCR, foram extraídos DNA de: 1carrapatos A. cajennense não infectados, provenientes da colônia mantida em laboratório; 2carrapatos $A$. cajennense não infectados, mas previamente "batizados" com a bactéria $B$. 
burgdorferi; 3-suspensão purificada de bactérias B. burdorferi. Toda as amostras foram testadas pelo protocolo de nested-PCR descrito acima.

A capacidade do protocolo da PCR de amplificar DNA de Borrelia não pertencente ao grupo B. burgdorferi sensu lato foi testada com carrapatos Argas miniatus infectados com Borrelia anserina (obtidos no Capítulo II deste trabalho), já que esta espécie de Borrelia é filogeneticamente distante das espécies do grupo B. burgdorferi sensu lato. 


\section{RESULTADOS}

\subsection{PADRONIZAÇÃO DA NESTED-PCR}

A padronização da Nested-PCR foi feita testando-se carrapatos A. cajennense não infectados, carrapatos A. cajennense não infectados "batizados" com B. burgdorferi e suspensão purificada de bactérias B. burdorferi. Após as nested-PCRs, nenhuma banda amplificada foi visualizada com o material de carrapatos não infectados, ao passo que bandas de intensidade semelhantes e no tamanho esperado (330 nt) foram visualizadas na reação feita com o DNA de carrapatos batizados com B. burgdorferi e com DNA de B. burdorferi purificada. Resultados semelhantes foram observados quando as amostras foram testadas apenas pela reação primária da PCR (somente com os primers FlaLL e FlaRL). Estes resultados evidenciam a eficiência do protocolo de extração, indicando que o DNA extraído do carrapato total não apresentou inibição significante da PCR.

Semelhantemente, a nested-PCR foi eficaz na amplificação de DNA de B. anserina das amostras de $A$. miniatus testadas (vide Capítulo II).

\subsection{COLETA DE CARRAPATOS}

De Janeiro a Fevereiro de 2005, foram coletados um total de 349 carrapatos, sendo 296 de vida livre, diretamente do ambiente através de armadilha de $\mathrm{CO}_{2}$, e 53 em parasitismo 
sobre eqüinos. Os carrapatos foram coletados em três locais com histórico de casos de Doença de Lyme-Simile: Itapevi, Mogi das Cruzes e São Paulo (Tabela 1). Todos carrapatos foram identificados como adultos da espécie Amblyomma cajennense.

Tabela 1 - Locais de coleta de carrapatos adultos (machos e fêmeas) da espécie $A$. cajennense, segundo o sítio de coleta

\begin{tabular}{cccccccc}
\hline \multirow{2}{*}{ Carrapatos } & \multicolumn{7}{c}{ LOCAL } \\
\cline { 2 - 8 } & \multicolumn{1}{c}{ Vale Verde (Itapevi) } & \multicolumn{2}{c}{ Mogi das Cruzes } & \multicolumn{2}{c}{ Parelheiros } & TOTAL \\
\cline { 2 - 8 } Machos & 105 & 10 & 28 & 6 & 10 & 0 & 159 \\
\multirow{2}{*}{ Fêmeas } & 114 & 25 & 33 & 12 & 6 & 0 & 190 \\
\hline TOTAL & 254 & Cavalo & Ambiente & Cavalo & Ambiente & Cavalo & \\
\hline
\end{tabular}

Em Itapevi, os carrapatos foram coletados no condomínio Vale Verde, segundo indicação do Dr. Natalino H. Yoshinari, do Laboratório de Investigação em Reumatologia, Hospital das Clínicas, Faculdade de Medicina, Universidade de São Paulo (LIM-17). Neste condomínio foram registrados os primeiros casos de DLS do Estado de São Paulo (YOSHINARI et al., 1992, 1993). Em Mogi das Cruzes, os carrapatos foram coletados em uma área suburbana habitada por eqüinos, onde ocorreu um caso de DLS em 2004 (Comunicação Pessoal) $^{6}$. Em São Paulo, os carrapatos foram colhidos no Condomínio Praias Paulistanas, na região de Parelheiros, onde casos de DLS foram registrados em 2003 (Comunicação pessoal) ${ }^{7}$.

\footnotetext{
${ }^{6}$ Informaçao fornecida pela Secretaria de Saúde da Prefeitura Municipal de Mogi das Cruzes em 2004.

${ }^{7}$ Informação fornecida pela SUCEN em 2003
} 


\subsection{PCR DOS CARRAPATOS COLHIDOS}

A reação de nested-PCR foi realizada com DNA de todos os 349 carrapatos coletados. As amostras foram testadas em pool de DNA proveniente de cada três carrapatos. Cada pool consistia em aproximadamente 500 ng de DNA total. Em cada bateria de reações eram incluídos um controle positivo (DNA de carrapato batizado com B. burdorferi) e três controles negativos (a mesma água utilizada para preparo do "mix" de reação). Todas amostras foram negativas à nested-PCR, uma vez que nenhuma banda visível, compatível com amplificação, foi visualizada nos géis de agarose corado com brometo de etídeo. Por outro lado, bandas compatíveis foram sempre visualizadas na amostra controle positivo.

Sendo assim, todos os 349 carrapatos colhidos nas três áreas foram negativos para a reação de Nested-PCR visando a amplificação do fragmento do gene FlaB.

\subsection{AMOSTRAS DE PACIENTES E DE CULTIVOS}

Foram analisadas seis amostras de sangue de pacientes, duas amostras de cultivos de sangue de paciente e duas amostras de biopsia de pele de um mesmo paciente, sendo uma do cotovelo e uma das costas, onde havia lesões compatíveis com eritema migratório e três amostras de carrapatos coletados de áreas com suspeita de DLS que foram triturados e inoculados em meio de cultivo BSK no Laboratório de Investigação em Reumatologia dos Hospital das Clínicas (LIM 17). Como controle positivo, utilizou-se DNA extraído de sangue humano "batizado" com B. burgdorferi. Em adição, foi testada uma única amostra de sangue 
de uma paciente de Mogi das Cruzes, da região de coleta dos A. cajennense deste Município. Essa pessoa foi diagnóstica e tratada como portadora de DLS, por um médico do próprio município. Também foi testada uma ninfa de Amblyomma sp, retirada em parasitismo de um paciente, identificado como Carlos, encaminhado ao Laboratório de Investigação em Reumatologia, Hospital das Clínicas (LIM-17) e enviada ao laboratório de Doenças Parasitárias- FMVZ - USP. O Paciente apresentava a seguinte sintomatologia: dores articulares e dor de cabeça.

Os resultados de todas as nested-PCRs foram negativos (Tabela 2).

Tabela 2 - Amostras enviadas pelo Laboratório de Investigação em Reumatologia, Hospital das Clínicas, Faculdade de Medicina, Universidade de São Paulo (LIM-17)

\begin{tabular}{|c|c|c|}
\hline Amostras & Origem do Material & $\begin{array}{c}\text { Resultado Nested - } \\
\text { PCR }\end{array}$ \\
\hline Geralda & Fragmento de pele com lesão (Cotovelo) & Negativo \\
\hline Geralda & Fragmento de pele com lesão (Costas) & Negativo \\
\hline Marli & Sangue & Negativo \\
\hline Gabriela & Sangue & Negativo \\
\hline Violante & Sangue & Negativo \\
\hline Felícia & Sangue & Negativo \\
\hline Ella & Sangue & Negativo \\
\hline Geralda & Sangue & Negativo \\
\hline Kátia & Sangue & Negativo \\
\hline Marli & Sangue em meio BSK & Negativo \\
\hline Marli & Sangue em meio SP4 & Negativo \\
\hline Ixodes didelphidis (DBM35) & Triturado e inoculado em meio BSK & Negativo \\
\hline Ixodes loricatus & Triturado e inoculado em meio BSK & Negativo \\
\hline Amblyomma cajennense & Triturado e inoculado em meio BSK & Negativo \\
\hline Carlos & Ninfa de Amblyomma (em parasitismo) & Negativo \\
\hline
\end{tabular}




\section{DISCUSSÃO}

Todos trabalhos que objetivaram a identificação direta do agente da Doença de LymeSímile no Brasil anteriormente publicados mostram resultados sem sucesso enquanto o diagnóstico sorológico é explorado em muitas publicações apresentando resultados positivos com o uso de antígenos não originais do Brasil.

Por não ter conhecimento da existência do agente causador do quadro denominado Doença de Lyme-Simile, os testes sorológicos realizados aqui no Brasil perdem os poderes analíticos e diagnósticos, sendo passíveis de falsos resultados positivos por reações cruzadas com outras espiroquetas ou mesmo outros tipos de bactérias.

A ausência de resultado positivo na investigação do agente causador da DLS, nesse trabalho, pode indicar uma prevalência muito baixa da espiroqueta ou ainda ausência da mesma nas populações de carrapatos da espécie $A$. cajennense avaliadas.

A suspeita da existência da B. lonestari ser a causadora da DLS no Brasil perde forças quando comparamos nossos resultados negativos com os obtidos nos EUA, onde o carrapato A. americanum é o vetor de $B$. lonestari. Naquele país, uma prevalência mínima de $5,6 \%$ de infecção por $B$. lonestari foi encontrada através da PCR para um total de 214 carrapatos $A$. americanum, coletados em vida livre (BACON et al., 2003). Além disso, DNA de B. lonestari foi encontrado em material de biópsia de lesão cutânea tipo eritema migrans em humanos (JAMES et al., 2001) e em sete $(8,7 \%)$ de 80 amostras de sangue de Veados-da-CaudaBranca, hospedeiros primários de $A$. americanum. Todos esses resultados foram obtidos pela nested-PCR para o gene $f l a B$, assim como realizado no presente trabalho.

Comparando esses resultados obtidos na América do Norte com os nossos resultados negativos, podemos levantar as seguintes hipóteses para os casos brasileiros de DLS: 
1. A prevalência do agente é muito baixa na população de $A$. cajennense, a ponto de não ter sido detectada na amostra total de 349 espécimes de A. cajennense testada no presente trabalho.

2- O vetor da DSL no Brasil não é a espécie $A$. cajennense.

3- $\mathrm{O}(\mathrm{s})$ agente(s) etiológico(s) de DLS no Brasil não pertence(m) ao gênero Borrelia. 


\section{RESUMO}

A doença de Lyme é uma doença causada pelas bactérias do complexo Borrelia burgdorferi sensu lato que são transmitidas por carrapatos do complexo Ixodes ricinus. A distribuição geográfica dessas bactérias é confirmada no Hemisfério Norte (América do Norte, Europa e Ásia). Suspeita-se que a enfermidade no Brasil está provavelmente relacionada a uma espécie de Borrelia diferente das espécies causadoras de doença de Lyme no hemisfério Norte e que o vetor sejam carrapatos do gênero Amblyomma. Por estas razões, a doença brasileira passou a ser chamada de Doença de Lyme-Símile (DLS). O presente trabalho investigou a presença de Borrelia spp em áreas onde foram relatados casos humanos de DLS no Estado de São Paulo. Para tal, foram processados um total de 349 carrapatos $A$. cajennense adultos coletados em áreas com suspeita de DLS, nove amostras de sangue ou tecidos de pacientes humanos com diagnóstico clínico e sorológico de DLS, duas amostras de caldas de meio BSK previamente inoculado com tecidos ou sangue de pacientes com suspeita de DLS, e três amostras de caldas de meio BSK previamente inoculado com carrapatos coletados de áreas com suspeita de DLS. Essas amostras tiveram seu DNA extraído e testado pela nested-PCR com primers específicos para porções do gene flagelina B (flaB), aptos a amplificar porções deste gene de qualquer espécie de Borrelia. Todas as amostras foram negativas pela nested-PCR, não evidenciando a presença de Borrelia sp nas amostras avaliadas. 


\section{Capítulo II}

\section{Caracterização molecular e isolamento em meio de cultura BSK de uma cepa de Borrelia anserina de Pedro Leopoldo, MG}

\section{INTRODUÇÃO}

A espiroquetose aviária é uma doença aguda e septicêmica de várias espécies de aves causada pela bactéria Borrelia anserina. A doença foi descrita pela primeira vez numa epidemia em gansos na Rússia (SAKHAROFF, 1891). Após alguns anos, no Brasil, Marchoux e Salimbeni (1903) incriminaram os carrapatos do gênero Argas como vetores da doença, que mais tarde foram confirmados por outros autores em outros países (DIAB; SOLIMAN, 1977; KNOWLES; GUPTA; BASU, 1932; PROWAZEK, 1909).

A maioria das publicações sobre espiroquetose foi publicada antes da década de 80 , em especial nos anos 40 a 60, quando a produção de frangos era composta por pequenas propriedades e muitas delas possuíam condições sanitárias pobres. Hoje a industria avícola, na maioria dos países, está muito avançada em resposta à globalização, industrialização, integração vertical e agregações onde grandes empresas de agronegócio controlam a indústria avícola em diferentes países.

Essas mudanças têm eliminado a possibilidade do carrapato se estabelecer nessa nova produção intensiva. Nos países onde a espiroquetose foi relatada e era tida como uma das doenças mais severas afetando a industria dos frangos no passado (ARAGÃO, 1911; GORRIE, 1950; KNOWLES; GUPTA; BASU, 1932; SA'IDU; AGBEDE; ABDU, 1995), a doença veio a ficar confinada a pequenas propriedades com produção para consumo próprio ou para comercialização local restrita, não tendo impacto econômico para o país. No entanto, o sistema de produção ao ar livre (principalmente produção de ovos) vem sendo uma 
tendência nos dias de hoje em resposta a uma maior preocupação com o bem-estar dos frangos criados em granjas. Embora ainda não descrito, esse tipo de tendência pode levar ao estabelecimento da população de Argas nesse sistema modificado de criação e conseqüentemente a reemergêngia da espiroquetose aviária (CAB, 2002).

B. anserina tem sido mantida em laboratório por várias passagens em frangos ou ovos embrionados (BARNES, 1997). A cripopreservação da B. anserina por um longo período foi alcançada com sucesso (DHAWEDKAR; DHANESAR, 1983; LABRUNA et al., 1999). Outro modo de manutenção da $B$. anserina é a manutenção de carrapatos do gênero Argas infectados com a bactéria. O Crescimento in vitro da B. anserina em meio Barbour-StoennerKelly (BSK) foi estabelecida, mas um único estudo relatou que o organismo perdeu sua virulência por volta da décima segunda passagem (LEVINE et al., 1990). Curiosamente uma cepa de B. anserina não cultivável em BSK foi descrita (SAMBRI et al., 1999).

No início do século vinte, $B$. anserina foi classificada com diferentes nomes taxonômicos (KNOWLES et al., 1932). Isto era justificado pelos resultados negativos obtidos nos testes de imunidades cruzadas em aves de laboratório com cepas de diferentes pontos geográficos. Atualmente, é bem conhecido que existem diferentes variedades antigênicas de B. anserina e a imunidade ativa pode ser especifica para determinadas variedades (DAMASSA; ADLER, 1979; NOPPA et al., 1995, SAMBRI et al., 1999; SONI; JOSHI, 1980;). No entanto, a caracterização molecular foi feita apenas de cepas de B. anserina originais dos Estados Unidos (BUNIKIS et al., 1998; MARCONI; GARON, 1992; MARTI RAS et al., 1996; PASTER et al., 1991). 


\section{OBJETIVO}

O Objetivo desse trabalho é o isolamento em meio BSK e a caracterização molecular de uma cepa de espiroqueta do Brasil, presumidamente identificada como B. anserina. 


\section{MATERIAL E MÉTODOS}

\subsection{OBTENÇÃO DA CEPA}

Em 1999, carrapatos Argas miniatus naturalmente infectados com espiroquetas foram coletados em um galinheiro no município de Pedro Leopoldo, MG. Os carrapatos infectados foram alimentados em frangos SPF, sendo a bactéria mantida em aves por várias passagens, através de inoculações de sangue infectado em aves sadias, e posteriormente pela criopreservação com dimetil-sulfoxido (DMSO) em nitrogênio líquido do soro de ave infectada (LABRUNA et al., 1999). Uma dessas amostras criopreservadas foi utilizada para o presente estudo, conforme descrito a seguir. A espiroqueta estudada foi designada de cepa PL.

\subsection{MANUTENÇÃO DA CEPA E OBTENÇÃO DE MATERIAL PARA ANÁLISE} MOLECULAR

A cepa PL, que estava criopreservada, foi descongelada e inoculada em dois frangos susceptíveis por via endovenosa (veia braquial), $1 \mathrm{ml} \mathrm{em} \mathrm{cada} \mathrm{animal.} \mathrm{Para} \mathrm{a} \mathrm{acomodação} \mathrm{das}$ aves foi desenvolvido um viveiro que mimetizasse a situação natural de um galinheiro infestado com carrapatos em estágio de ninfa e adultos da espécie Argas miniatus (aproximadamente 350 carrapatos). Os frangos passaram por um período de adaptação no viveiro de seis dias antes de serem inoculados com a cepa PL de espiroquetas. Após dois dias 
os frangos apresentavam inapetência, apatia e diarréia esverdeada, sinais característicos do quadro de espiroquetose aviária (Figura 1). Para certificação da infecção, fez-se a leitura diária de esfregaço sanguíneo fixado em álcool metílico e corado por 40 minutos por corante Giemsa. A leitura foi feita em microscopia óptica na objetiva de imersão (1000x).

Com quatro dias pós-inoculação, foi coletado $2 \mathrm{ml}$ de sangue de cada frango e inoculado por via intramuscular em mais dois frangos mantidos fora do viveiro com carrapatos. A leitura do esfregaço sanguíneo foi feita diariamente até apresentarem mais de 10 bactérias por campo visual (Figura 2) para posterior coleta de sangue e obtenção do soro contendo espiroquetas.

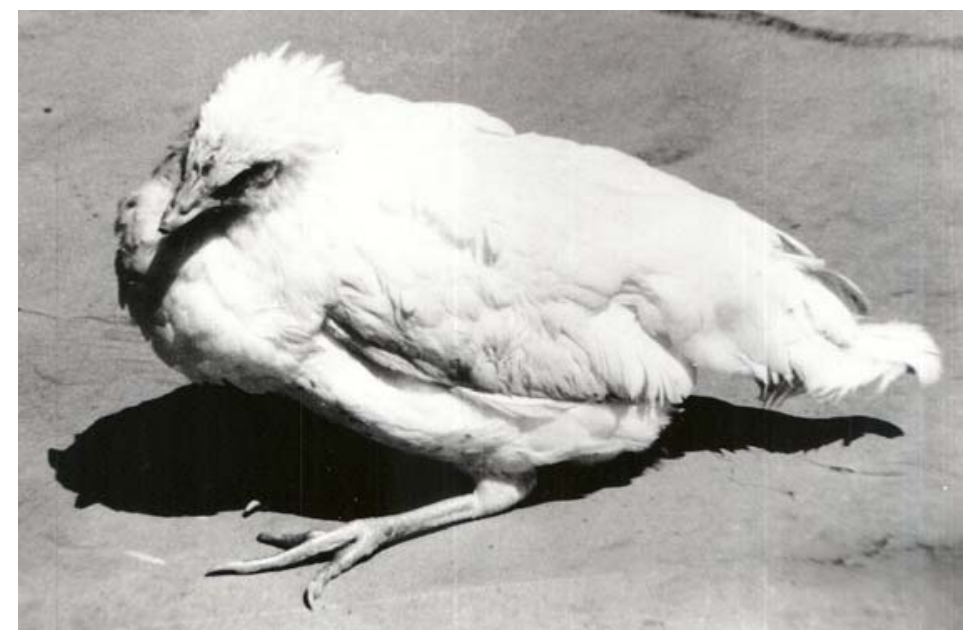

Figura 1 - Ave com espiroquetose aviária, apresentando apatia e prostração 


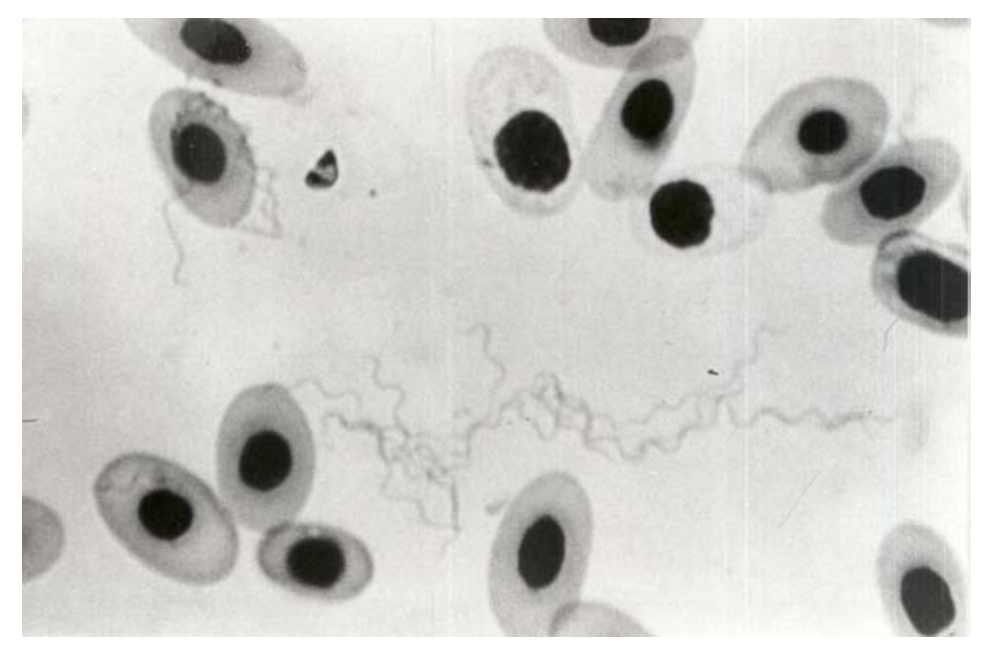

Figura 2 - Microscopia óptica de lâmina de esfregaço sanguíneo da ave com espiroquetose em estágio de bacteremia com mais de 10 espiroquetas por campo. Coloração Giemsa. Objetiva: 1000x

As etapas e cronologia do processo para obtenção de soro contendo espiroquetas viáveis está demonstrada na tabela 3.

Tabela 3 - Processo realizado para obtenção de espiroqueta a partir do soro de frango

\begin{tabular}{|c|c|c|c|c|c|c|c|}
\hline \multirow[b]{2}{*}{ Animais } & \multicolumn{7}{|c|}{ Dias } \\
\hline & 0 & $6^{\circ}$ & $9^{\circ}$ & $10^{\circ}$ & $12^{\circ}$ & $13^{\circ}$ & $14^{\circ}$ \\
\hline Frango 1 & $\begin{array}{c}\text { Acomodação } \\
\text { no viveiro }\end{array}$ & $\begin{array}{l}\text { Inoculação } \\
\text { da cepa }\end{array}$ & $\begin{array}{l}\text { inapetência, } \\
\text { apatia e diarréia } \\
\text { esverdeada }\end{array}$ & $\begin{array}{l}\text { Coleta do } \\
\text { sangue para } \\
\text { passagem }\end{array}$ & $\begin{array}{c}\text { Esfregaço: }<10 \\
\text { bactérias por } \\
\text { campo }\end{array}$ & Eutanásia & 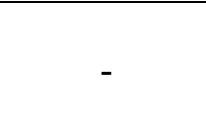 \\
\hline Frango 2 & $\begin{array}{c}\text { Acomodação } \\
\text { no viveiro }\end{array}$ & $\begin{array}{l}\text { Inoculação } \\
\text { da cepa }\end{array}$ & $\begin{array}{l}\text { inapetência, } \\
\text { apatia e diarréia } \\
\text { esverdeada }\end{array}$ & $\begin{array}{l}\text { Coleta do } \\
\text { sangue para } \\
\text { passagem }\end{array}$ & $\begin{array}{c}\text { Esfregaço: }<10 \\
\text { bactérias por } \\
\text { campo }\end{array}$ & Eutanásia & - \\
\hline Frango 3 & - & - & 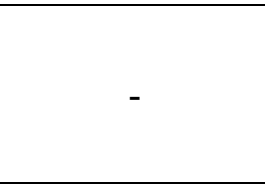 & $\begin{array}{l}\text { Inoculação } \\
\text { do sangue } \\
\text { (frango 1) }\end{array}$ & $\begin{array}{l}\text { inapetência, } \\
\text { apatia e diarréia } \\
\text { esverdeada }\end{array}$ & $\begin{array}{l}\text { Esfregaço: } \\
>10 \\
\text { bactérias } \\
\text { por campo }\end{array}$ & $\begin{array}{c}\text { Obtenção } \\
\text { do soro } \\
\text { com } \\
\text { espiroqueta }\end{array}$ \\
\hline Frango 4 & - & - & - & $\begin{array}{l}\text { Inoculação } \\
\text { do sangue } \\
\text { (frango 2) }\end{array}$ & $\begin{array}{l}\text { inapetência, } \\
\text { apatia e diarréia } \\
\text { esverdeada }\end{array}$ & $\begin{array}{l}\text { Esfregaço: } \\
>10 \\
\text { bactérias } \\
\text { por campo }\end{array}$ & $\begin{array}{c}\text { Obtenção } \\
\text { do soro } \\
\text { com } \\
\text { espiroqueta }\end{array}$ \\
\hline
\end{tabular}




\subsection{ANÁLISE MOLECULAR}

A partir do sangue, fígado e baço coletado dos frangos 3 e 4, após realizado a eutanásia, foi feita a extração de DNA para a realização da reação de PCR utilizando o Kit comercial, Dneasy Tissue Kit (Qiagen Chatsworth, CA) seguindo os protocolos de extração de DNA de sangue total com células nucleados e de tecido animal.

A PCR foi feita baseada em fragmento de dois genes de Borrelia, 16sRNA (rrs) e Flagelina (flaB). Para o gene rrs utilizou-se os primers Rec4 (5'ATGCTAGAAACTGCATGA-3') e Rec9 (5'-TCGTCTGAGTCCCCATCT-3'), os quais amplificam um fragmento de 519-nt de Borrelia spp (MARTI RAS et al., 1996) num volume final de $50 \mu$ l contendo $5 \mu \mathrm{l}$ da amostra de DNA, cada primer a $1.0 \mu \mathrm{M}$, Tris- $\mathrm{HCl}(10 \mathrm{mM})$, $\mathrm{MgCl}_{2}(1.5 \mathrm{mM})$, dNTP $(1.25 \mathrm{mM})$ e TaqDNA polimerase (1.5 U). O ciclo de temperatura e tempo consistiu em uma desnaturação inicial por 3 minutos a $95^{\circ} \mathrm{C}$, seguida de 35 ciclos, cada um consistindo em uma desnaturação a $95^{\circ} \mathrm{C}$ por 1 minuto, anelamento a $55^{\circ} \mathrm{C}$ por 1 minuto e extensão a $72^{\circ} \mathrm{C}$ por 1 minuto, e uma extensão final a $72^{\circ} \mathrm{C}$ por 10 minutos.

Para o gene $f l a B$ os primers utilizados foram: FlaLL (5'ACATATtCAGATGCAGACAGAGGT-3') e FlaRL (5'GCAATCATAGCCATTGCAGATTGT-3') os quais amplificam um fragmento de Borrelia spp de 658-nt (BARBOUR et al., 1996) e os primers A $\left(5^{\prime}\right.$ TCtGAtGATGCTGCTGGTATGG-3') e D (5'-AGGTTTTCAATAGCATACTC-3'), os quais amplificam um fragmento de 739-nt (GÜNER et al., 2003), sendo parte do produto desse par de primers sobreposto ao do primeiro par. As concentrações e volumes foram as mesmas utilizadas na reação do gene rrs. Quanto ao ciclo de tempo e temperatura para o par FlaLL e FlaRL, apenas o número de ciclos foi alterado, passando-se para 40 ciclos. Para o par 
A e D, a temperatura de anelamento foi alterada para $50^{\circ} \mathrm{C}$, com 35 ciclos. Para cada reação, um controle positivo (DNA de Borrelia burgdorferi cepa G39/40) e um controle negativo (água) foram incluídos.

O produto de PCR no tamanho esperado foi purificado utilizando ExoSap (USB) e seqüenciado em seqüenciador automático (Applied Biosystens/Perkin Elmer, modelo ABI Prism 310 Genetic, Califórnia, EUA) de acordo com protocolo do fabricante. As seqüências parciais obtidas foram submetidas à análise no BLAST (ALTSCHUL et al., 1990) para determinar a similaridade com outras seqüências disponíveis no GenBank. A análise filogenética foi inferida para o gene flaB utilizando-se o programa MEGA versão 3.1 (KUMAR et al., 2004). Para este propósito, a seqüência parcial do flaB gerada no seqüenciamento foi alinhada com as seqüências correspondentes de outras espécies de Borrelia disponíveis no GenBank, utilizando-se o algoritmo CLUSTAL. A distância filogenética entre seqüências homologas foi calculada através do modelo Kimura doisparâmetros (K-2P). Um dendograma foi construído pelo método "neighbor-joining". Valores de confiança para ramos individuais da árvore resultante foram determinados pela análise de bootstrap com 1000 repetições.

\subsection{ISOLAMENTO BACTERIANO IN VITRO}

O isolamento da cepa de espiroqueta foi realizado a partir de soro de frango infectado naturalmente por carrapatos da espécie $A$. miniatus da colônia mantida em nosso biotério. $\mathrm{O}$ animal infectado foi sacrificado e feito a coleta de $20 \mathrm{ml}$ sangue total em tubo Falcon de $50 \mathrm{ml}$ estéril para dessorar segundo o protocolo descrito por Labruna et al. (1999). Obteve-se $7 \mathrm{ml}$ 
de soro com as espiroquetas sendo utilizado $0,5 \mathrm{ml}$ para inoculação em $7 \mathrm{ml}$ do meio BSK acondicionado em tubo Falcon de 10ml. Todo o processo de inoculação foi feito em fluxo laminar com material estéril.

O crescimento bacteriano foi acompanhado a cada dois dias para se padronizar o tempo ideal para repicar em novo meio de cultura. Pingava-se em uma lâmina de microscopia $20 \mu 1$ do cultivo e cobria-se com uma lamínula de 20 x 20mm e observava-se em microscopia de campo escuro.

\subsection{SOROLOGIA}

Um dos meios BSK inoculados, após cinco dias de incubação, foi centrifugado para sedimentação das espiroquetas. Após descarte do sobrenadante, as espiroquetas foram inativadas com azida sódica a 0,01\% em $100 \mathrm{ml}$ de tampão fosfato (PBS, pH 7,4) utilizado para resuspender as espiroquetas. Um volume de $10 \mu \mathrm{l}$ desta suspensão foi acondicionado a cada poço em lâminas de vidro contendo 12 poços, próprias para confecção de antígeno para RIFI. As lâminas contendo o antígeno bruto de espiroquetas foram fixadas em acetona e congeladas a $-80^{\circ} \mathrm{C}$.

Três novas aves com 15 dias de vida foram alocadas no viveiro com a colônia de $A$. miniatus infectados. Após oito dias, as aves apresentaram sinais clínicos de espiroquetose, mas se recuperaram clinicamente após 2-3 dias. No $21^{\circ}$ dia, $3 \mathrm{ml}$ de sangue foi coletado de cada ave para a obtenção do soro. O soro desses animais foi testado pela RIFI, utilizando-se as lâminas com antígeno bruto da espiroqueta isolada, conforme descrito acima. $\mathrm{O}$ protocolo de RIFI utilizado foi o mesmo realizado para outros agentes bacterianos (HORTA et al., 
2004), porém empregando-se o soro dos frangos apenas na diluição de 1:64 e o conjugado anti-galinha produzido em coelho (Sigma), como anticorpo secundário. 


\section{RESULTADOS}

\subsection{ANÁLISE MOLECULAR}

O Tamanho das bandas obtidas com a amplificação na PCR com o DNA extraído do soro, fígado, baço e cultivo em meio BSK foram os esperados, em todas as reações (Figura 3). Para o gene 16s rRNA ( $r r s$ ), o fragmento único de 484-nt foi seqüenciado (Tabela 4), o qual apresentou alta similaridade com a seqüência correspondente da cepa Norte Americana de $B$. anserina disponível no GenBank (Tabela 5). Para o gene flaB, o fragmento seqüenciado foi de 764-nt (Quadro 1), o qual também mostrou alta similaridade com o gene correspondente da cepa Norte Americana de B. anserina no GenBank (Tabela 5). Comparado com a seqüência parcial do gene homologo flaB disponível no GenBank, a seqüência de B. anserina (X75201) foi a mais próxima da seqüência da cepa Brasileira (Tabela 5). Essas duas seqüências foram agrupadas num grupo monofilético pelo análise filogenética, pelo método neighbor-joining, com $100 \%$ de suporte bootstrap (Figura 4 ). 


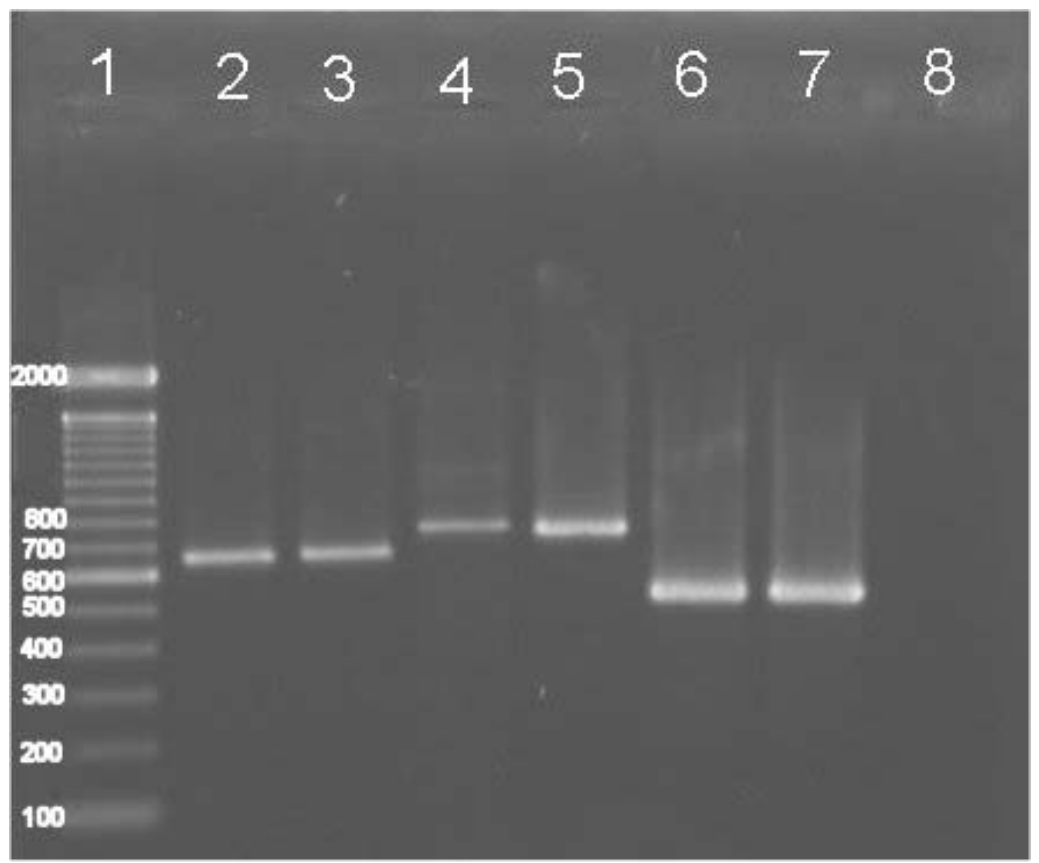

Figura 3 - PCR dos genes flaB e rrs analisado em gel de Agarose a 1,5\% corado com Brometo de Etídeo. 1-padrão de peso molecular (100pb); 2Controle positivo (B. burgdorferi) para os primers FlaRL/FlaLL (gene FlaB); 3-Cepa PL de espiroqueta para os primers FlaRL/FlaLL (gene FlaB); 4- Controle positivo (B. burgdorferi) para os primers A/D (gene FlaB); 5- Cepa PL de espiroqueta para os primers A/D (gene $F l a B$ ); 6- Controle positivo (B. burgdorferi) para os primers Rec4/Rec9 (gene $r r s$ ); 7- Cepa PL de espiroqueta para os primers Rec4/Rec9 (gene rrs); 8-controle negativo (Água)

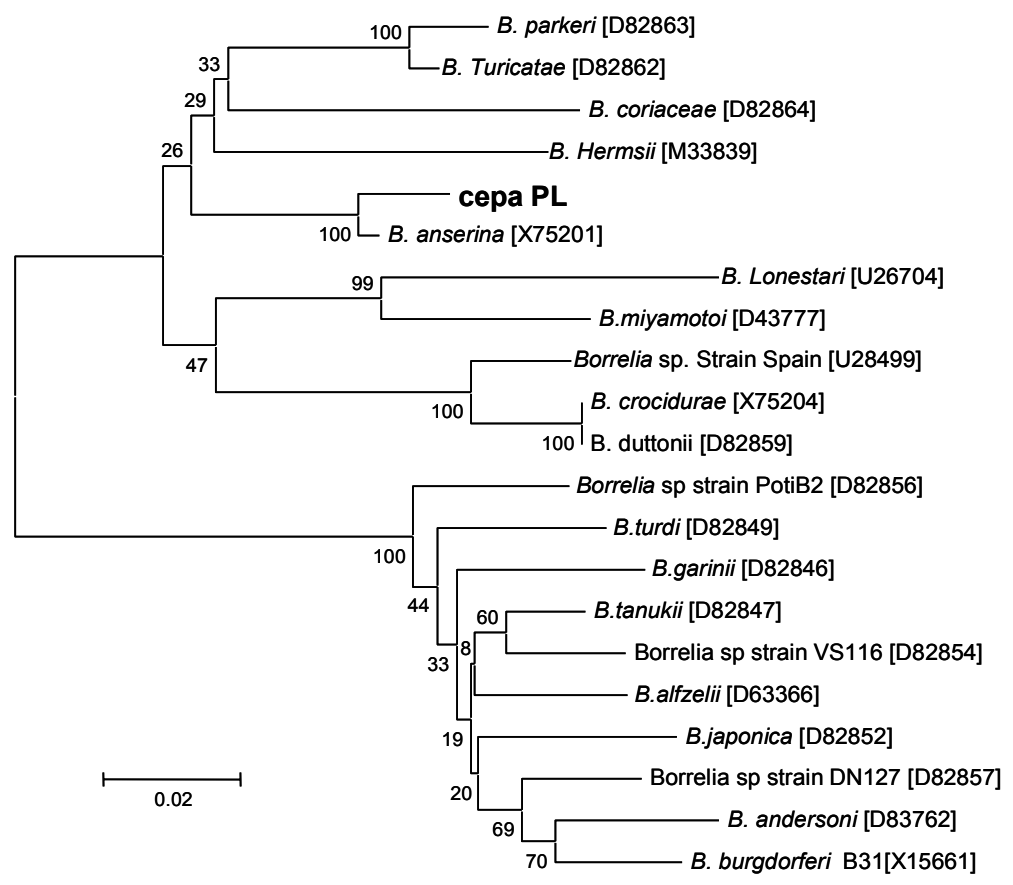

Figura 4 - Árvore filogenética baseada na comparação das seqüências parciais do gene da proteina flagelina ( $f l a B)$ das espécies de Borrelia. A amostra de espiroqueta isolada no presente trabalho é designada como cepa PL 


\begin{tabular}{|c|c|}
\hline Gene & Seqüência \\
\hline$r r s$ & $\begin{array}{l}\text { TTACATGCTGGTAACaGACaATAAGGGTTGCGCTCGTTGCGGGACTTAACCCAACACCTCACAGCACGAGCTG } \\
\text { ACGACAACCATGCAGCACCTGTATACAGACCCCAAACGGGGAATAGTTATCTCTAACTACATCCTGTATATG } \\
\text { TCAAGCCCTGGTAAGGTTCCTCGCGTATCATCGAATTAAACCACATGCTCCACCGCTTGTGCGGGCCCCCGTC } \\
\text { AATTCCTTTGAGTTTCACTCTTGCAAGCATACTCCCCAGGCGGCACACTTAACACGTTAGCTTCGGTACTAAC } \\
\text { CTTTCGATTAACACCAAGTGTGCATCGTTTACAGCATAGACTACCAGGGTATCTAATCCTGTTTGCTCCCTAT } \\
\text { GCTTTCGTGACTCAGCGTCAGTCTTGACCTAGAAGTTCGCCTTCGCCTCTGGTATTCTTCCTGATATCAACAGA } \\
\text { TTCCACCCCTACACCAGGAATTCTAACTTCCCCTATCAGACTCTAG }\end{array}$ \\
\hline flaB & $\begin{array}{l}\text { ATGCTCAAATTAGAGGATTATCTCAAGCTTCTAGAAATACTTCAAAAGCTATAAATTTTATTCAAACAACAGA } \\
\text { AGGAAATTTAAATGAGGTAGAGAAAGTATTAGTAAGAATGAAAGAACTTGCTGTTCAATCTGGTAATGGTAC } \\
\text { GTATTCAGATGCAGACAGAGGTCCATTCAAATTGAAATTGAGCAACTTACAGATGAAATTAACAGAATTGC } \\
\text { TGATCAAGCTCAATATAATCAAATGCATATGTTGTCTAATAAGTCAGCTGCTCAAAATGTAAGAACAGCTGA } \\
\text { AGAGCTTGGAATGCAGCCTGCAAAAATTAACACACCAGCATCTCTATCTGGATCACAAGCTTCATGGACATT } \\
\text { AAGAGTACATGTGGGCGCAAATCAGGATGAAGCAATTGCTGTTAATATTTATGCAGCTAATGTTGCAAATCT } \\
\text { TTTTGCAGGTGAAGGTGCTCAGGCTGCTCCAGCTCAAGAGGGAGCACAACAAGAGGGAGTACAAGCAACTC } \\
\text { CAGCTCCAGTAGCTGCTCCGACTCCAGGTGGGGTTAATTCTCCAATTAATGTTATAACTGCTGTTGATGCTAA } \\
\text { TATGTCACTTGCAAAGATAGAAGATGCTATTAGAATGGTAAGTGATCAAAGAGCAAACCTTGGTGCTTTCCA } \\
\text { AAATAGGCTTGAATCTATTAAAGATAGCACAGAATATGCTATTGAAAACTTAAAAGCATCTTATGCTCAAAT } \\
\text { TAAAGAtGCAACAATGACAGATGAAATTGTAGCATCTACAACT }\end{array}$ \\
\hline
\end{tabular}

Quadro 1 - Seqüência dos fragmentos gene $r r s$ e $f l a B$ da cepa de espiroqueta estudada

Tabela 5 - Relação de identidade para os fragmentos de 484-nt do genes $r r s$ e de 764-nt do gene flaB de uma amostra de espiroqueta (cepa PL) originalmente isolada do carrapato Argas miniatus do município de Pedro Leopoldo, MG

\begin{tabular}{lll}
\hline Número de acesso do GenBank & \multicolumn{1}{c}{ Organismo } & Similaridade (\%) \\
\hline rrs & Borrelia anserina (strain ES from USA) & $99.8(483$ of 484$)$ \\
U42284 & B. duttonii & $99.6(482$ of 483$)$ \\
AB113315 & B. hermsii & $99.2(480$ of 484$)$ \\
AY597674 & B. anserina (strain not specified from USA) & $98.7(754$ of 764$)$ \\
flab & B. hermsii & $93.4(714$ of 764$)$ \\
X75201 & B. parkeri & $93.3(713$ of 764$)$ \\
AY597806
\end{tabular}




\subsection{ISOLAMENTO DA ESPIROQUETA IN VITRO}

Após verificar que o soro obtido das aves continha um grande numero de espitoquetas viáveis e com alta motilidade, pela microscopia de campo escuro, 0,5 $\mathrm{ml}$ deste soro foi inoculado em $7 \mathrm{ml}$ de meio BSK. No quinto dia pós-inoculação, o meio tornou-se túrgido e um alto número de espiroquetas viáveis foi observada na microscopia de campo escuro. Nesse momento (5 dias após a inoculação), as espiroquetas se apresentaram em grande quantidade quando então, $0,5 \mathrm{ml}$ do meio foi repicado para um novo meio e os restante congelado a $80^{\circ} \mathrm{C}$, metade com DMSO a $10 \%(10: 1)$ e a outra metade com Glicerol $80 \%$ a $10 \%$ com o meio (10:2). O repique foi repetido por mais seis vezes, totalizando sete passagens. Sempre após o repique o cultivo restante era aliquotado e criopreservado. A viabilidade das amostras congeladas foi checada com sucesso pelo descongelamento de uma alíquota congelada e inoculação da mesma em um novo meio BSK.

Da aliquota da sétima passagem congelada foi extraído o DNA das espiroquetas e feito a PCR utilizando-se os primers para o gene flaB. A seqüência do fragmento amplificado mostrou $100 \%$ de identidade como a seqüência parcial do flab gerada a partir do DNA extraído do fígado, baço e soro coletado dos frangos infectados. 


\subsection{SOROLOGIA}

A RIFI com os soros das aves, das duas coletas, mostrou forte reatividade (Figura 5)

com o antígeno bruto de espiroquetas. Os soros controle negativo, de aves não infectados, não apresentaram reação com as espiroquetas.

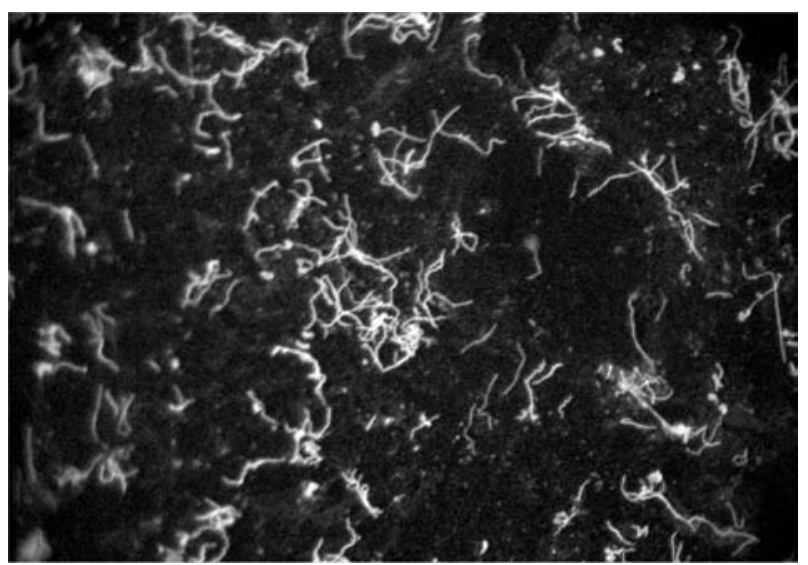

Figura 5 - Reação de imunoflorescencia indireta (RIFI) com soro de aves infectadas com a cepa PL utilizandose a própria cepa PL de espiroquetas como antígeno bruto 


\section{DISCUSSÃO}

Esse estudo trata-se do primeiro isolamento in vitro e caracterização molecular de uma cepa de B. anserina originária da América Latina. Anteriormente, a espiroquetose aviária foi relatada em alguns países dessa região (Argentina, Brasil, Guiana, Guadalupe e Martinique) (BOERO, 1957; KNOWLES et al., 1932; LABRUNA et al., 1999), mas o agente etiológico nunca foi caracterizado por ensaios sorológicos e moleculares.

A caracterização molecular e análise filogenético do presente trabalho, associados aos dados clínicos e epidemiológicos anteriormente descritos (LABRUNA et al., 1999) não deixam dúvidas de que a cepa de espiroqueta PL do Brasil é pertence a espécie $B$. anserina. Análises filogenéticas da seqüência parcial do gene flaB da cepa PL mostraram que esta cepa diferenciou em 10 nucleotídeos da cepa de B. anserina da América do Norte, refletindo em pelo menos 1 amino-ácido diferente. Como o gene flaB codifica uma proteína de membrana externa, essa diferença pode ser ligada a uma possível diferença antigênica entre as duas cepas de B.anserina, já que diferentes variantes antigênicas de $B$. anserina têm sido relatadas (DAMASSA; ADLER, 1979; SAMBRI et al., 1999SONI; JOSHI, 1980;). De fato, anticorpos cepa-específicos têm sido relatados contra a infecção por B. anserina (SAMBRI et al., 1999).

Há décadas, a espiroquetose aviária foi considerada uma das doenças mais ameaçadoras em criações de frangos por todo o mundo, levando vários paises ao desenvolvimento de vacinas inativadas (ARAGÃO, 1911; GORRIE, 1950; KNOWLES; GUPTA; BASU, 1932). Atualmente, a espiroquetose aviária está praticamente confinada a pequenas criações de subsistência ou venda para locais restritos, onde há o vetor (Argas spp.). Nesse contexto, a infecção assume níveis endêmicos nos quais a doença em aves é raramente observada. 
Aves recém-nascidas são resistentes à doença devido aos anticorpos maternos, desenvolvendo imunidade adquirida durante o crescimento. Neste caso, a doença é praticamente restrita a aves susceptíveis introduzidas nas criações. Este contexto partiCular tem gerado pouco ou nenhum interesse dos laboratórios veterinários para a produção de vacinas contra a espiroquetose aviária (CAB, 2002). Além da importância histórica da espiroquetose aviária, o agente é encontrado no mundo todo e a sua reemergência como um importante patógeno veterinário pode ocorrer no futuro. Essa reemergência depende basicamente da mudança do sistema de criação, favorecendo a introdução e estabelecimento do carrapato vetor (Argas spp). 


\section{RESUMO}

Borrelia anserina, o agente causador da espiroquetose aviária, tem distribuição mundial e é transmitida primordialmente pelo carrapato do gênero Argas. O isolamento in vitro e a caracterização molecular da $B$. anserina foi conseguida apenas em cepas de $B$. anserina dos Estados Unidos. Esse trabalho relata o primeiro isolamento de $B$. anserina em meio BSK e a caracterização molecular de uma cepa de espiroqueta aviária presumidamente identificada como B. anserina, originada de carrapatos Argas miniatus naturalmente infectados em Pedro Leopoldo, Minas Gerais. O isolamento in vitro e caracterização molecular da espiroqueta aviária foi feito a partir da inoculação de soro infectado, contendo espiroquetas viáveis, em meio BSK. O soro, baço, fígado e o próprio cultivo foram utilizados para amplificação na PCR para os genes rrs e flaB, seguido de seqüenciamento dos mesmos. O isolamento da espiroqueta foi obtido com sucesso, com várias passagens realizadas. A análise genética das seqüências do isolado mostrou 99.8\% (483 de 484-bp) e 98.7\% (754 de 764-bp) de similaridade às seqüências correspondentes dos genes $r r s$ e flaB de $B$. anserina, respectivamente, disponíveis no GenBank. Pela análise filogenética inferida pela seqüência parcial do gene $f l a B$, a cepa Brasileira agrupou-se com a seqüência de $B$. anserina dos EUA. Os resultados indicam a cepa brasileira estudada, designada de cepa PL, pertence à espécie $B$. anserina. 


\section{CONCLUSÕES}

a) Permanece desconhecido o agente causador da Doença de Lyme-Símile no Brasil;

b) A reação de nested-PCR mostrou-se eficiente para a detecção de DNA do gênero Borrelia.

c) Os carrapatos Amblyomma cajennense coletados para análise não estavam infectados por nenhuma espécie de Borrelia.

d) Se o agente da Doença de Lyme-Símile pertencer ao gênero Borrelia, e se este for transmitido pelo carrapato Amblyomma cajennense, o agente se apresenta numa prevalência de infecção muito baixa na população de carrapato.

e) A cepa PL de espiroqueta, causadora de espiroquetose aviária no Brasil, pertence à espécie Borrelia anserina.

f) Há diferenças genéticas entre as cepas de B. anserina do Brasil e da América do Norte, sendo traduzidas em pelo menos um aminoácido diferente entre as cepas analisadas.

g) A cepa PL de B. anserina pode ser cultivada em meio BSK. 


\section{REFERÊNCIAS}

ABEL, I. S.; MARZAGAO, G.; YOSHINARI, N.H.; SCHUMAKER, T. T. Borrelia-like spirochetes recovered from ticks and small mammals collected in the Atlantic Forest Reserve, Cotia county, State of Sao Paulo, Brazil. Memorias do Instituto Oswaldo Cruz, v. 95, n. 5, p. 621-624, 2000.

ALTSCHUL, S. F.; GISH, W.; MILLER, W.; MYERS, E. W; LIPMAN, D. J. Basic local alignment search tool. Journal of Molecular Biology, v. 215, n. 3, p. 403-410, 1990.

ARAGÃO, H. B. Soroterapia e vacinação na espiroquetoze das galinhas. . Memorias do Instituto Oswaldo Cruz, n. 3, p. 3-39, 1911.

AZULAY, R. D.; AZULAY-ABULAFIA, L., SODRE, C. T.; AZULAY, D. R.; AZULAY, M. M. Lyme disease in Rio de Janeiro, Brazil. International Journal of Dermatology, v. 30, n. 8, p. 569-571, 1991.

BACON, R. M.; GILMORE, R. D.; QUINTANA, M.; PIESMAN, J.; JOHNSON, B. J. B. DNA Evidence of Borrelia lonestari in Amblyomma americanum (Acari: Ixodidade) in Southeast Missouri. Journal of Medical Entomology, v. 40, n. 4, p. 590-592, 2003.

BARBOUR, A. G.; MAUPIN, G. O.; TELTOW, G. J.; CARTER, C. J.; PIESMAN, J. Identification of an uncultivable Borrelia species in the hard tick Amblyomma americanum: possible agent of a Lyme disease-like illness. Journal of Infectious Diseases, v. 173, n. 2, p. 403-409, 1996.

BARNES, H. J. Spirochetosis (Borreliosis). In: CAMEK, B. W.; BARNES, H. J.; BEARD, C. W.; MCDOUGALD, L. R.; SAIF, Y. M. (Ed.). Disease of poultry. Iowa: Iowa State University Press Ames, 1997, p. 318-324.

BARROS-BATTESTI, D. M. Estudo de carrapatos e pequenos mamíferos silvestres naturalmente infectados com espiroquetas semelhantes a Borrelia, no município de Itapevi, Estado de São Paulo. 1998. 116 p. Tese (Doutorado) - Faculdade de Saúde Pública, Universidade de São Paulo, São Paulo, 1998.

BENNETT, C. E. Ticks and Lyme disease. Advances in Parasitology, v. 36, p. 343-405, 1995. 
BOERO, J. J. Las garrapatas de la Republica Argentina (Acarina-Ixodoidea). Buenos Aires: Universidad de Buenos Aires, 1957. p. 113.

BUNIKIS, J.; LUKE, C. J.; BUNIKIENE, E.; BERGSTROM, S.; BARBOUR, A. G. A surface-exposed region of a novel outer membrane protein (P66) of Borrelia spp. is variable in size and sequence. Journal of Bacteriology, v. 180, n. 7, p. 1618-1623, 1998.

CAB International. 2002. Borrelia anserina [original text by M.B. Labruna] In: Animal Health and Production Compendium. Wallingford, UK: CAB International. (CD rom)

CHOMKZYNSKI, P. A. A. A reagent for the single-step simultaneous isolation of RNA, DNA and proteins from cell and tissue samples. Biotechniques, v. 15, n. 3, p. 532-537, 1993.

COSTA, I. P.; BONOLDI, V. L.; YOSHINARI, N. H. Search for Borrelia sp. in ticks collected from potential reservoirs in an urban forest reserve in the State of Mato Grosso do Sul, Brazil: a short report. Memorias do Instituto Oswaldo Cruz, v. 97, n. 5, p. 631-635, 2002.

COSTA, I. P.; YOSHINARI, N. H.; BARROS, P. J.; BONOLDI, V. L.; LEON, E. P.; ZEITUNE, A. D.; COSSERMELLI, W. Doença de Lyme em Mato Grosso do Sul: relato de três casos clínicos, incluindo o primeiro relato de meningite de Lyme no Brasil. Resvista do Hospital das clinicas Faculdade de Medicina de Sao Paulo, v. 51, n. 6, p. 253-257, 1996.

DAMASSA, A. J.; ADLER, H. E. Avian spirochetosis: natural transmission by Argas (Persicargas) sanchezi (Ixodoidea: Argasidae) and existence of different serologic and immunologic types of Borrelia anserina in the United States. American Journal of Veterinary Research, v. 40, n. 1, p. 154-157, 1979.

DHAWEDKAR, R. G.; DHANESAR, N. S.; Preservation of Borrelia anserina by liquid nitrogen refrigeration. Indian Journal of Animal Science, v. 53, p. 1124-1127, 1983.

DIAB, F. M.; SOLIMAN, Z. R. An experimental study of Borrelia anserina in four species of Argas ticks. 1. Spirochete localization and densities. Zeitschrift für Parasitenkunde, v. 53, n. 2, p. 201-212, 1977.

FELZ, M. W.; CHANDLER JR, F. W.; OLIVER JR, J. H.; RAHN, D. W.; SCHRIEFER, M. E. Solitary erythema migrans in Georgia and South Carolina. Archives of Dermatology, v. 135, n. 11, p. 1317-1326, 1999.

FILGUEIRA, A. L.; TROPPE, B. M.; GONTIJO FILHO, P. P. Doença de Lyme. Rio Dermatológico, v. 2, p. 4-5, 1989. 
GEHRKE, F. S. Estudo da prevalencia de Borrelia spp, Ehrlichia spp e Rickettsia spp em carrapatos coletados no Estado de Rondônia, Amazonia Ocidental. 2002. 95 p. Dissertação (Mestrado) - Instituto de Ciências Biomédicas, Universidade de São Paulo, São Paulo, 2002.

GORRIE, C. J. R. Vaccination against spirochetosis in fowls. Australian Veterinary Journal, v. 26, n.11, p. 308-315, 1950.

GUIMARÃES, J. H.; TUCCI, E. C.; BARROS-BATTTESTI, D. M. Ectoparasitos de importância veterinária. São Paulo: Editora Plêiade,. 2001, 213 p.

GÜNER, E. S.; HASHIMOTO, N.; KADOSAKA, T.; IMAI, Y.; MASUZAWA, T. A novel, fast-growing Borrelia sp. isolated from the hard tick Hyalomma aegyptium in Turkey. Microbiology, v. 149, p. 2539-2544, 2003

HALL, T. A. BioEdit: a user-friendly biological sequence aligment editor and analysis program for Windows 95/98/NT. Nucleics Acids Research, v. 41, p. 95-98, 1999.

HORTA M. C.; LABRUNA, M. B.; SANGIONI, L. A.; VIANNA, M. C. B.; GENNARI, M. S.; GALVÃO, M. A. M.; MAFRA, C.; VIDOTTO, O.; SCHUMAKER, T. T.; WALKER, D. $\mathrm{H}$. Prevalence of antibodies to spotted fever group rickettsiae in humans and domestic animals in a Brazilian spotted fever endemic area in the state of São Paulo, Brazil: serological evidence for infection by Rickettsia rickettsii and another spotted fever group rickettsia. The American Journal of Tropical Medicine and Hygieni, v. 71, n. 1, p. 93-97, 2004.

JAMES, A. M.; LIVERIS, D.; WORMSER, G. P.; SCHWARTZ, I.; MONTECALVO, M. A.; JOHNSON, B. J. Borrelia lonestari infection after a bite by an Amblyomma americanum tick. Journal Infectious Diseaes, v. 183, p. 1810-1814, 2001.

KNOWLES, R.; GUPTA, B. M.; BASU, B. C. Studies in avian spirochetosis. Indian Medical. Research. Mememories, v. 22, p. 1-122, 1932.

KUMAR, S.; TAMURA, K.; NEI, M. MEGA3: Integrated software for Molecular Evolutionary Genetics Analysis and sequence alignment. Briefings in bioinformatics, v. 5, p. 150-163, 2004.

LABRUNA, M. B.; KASAI, N.; FERREIRA, F.; FACCINI, J. L. H.; GENNARI, S. M. Seasonal dynamics of ticks (Acari: Ixodidae) on horses in the state of São Paulo, Brazil. Veterinary Parasitology, v. 105, n. 1, p. 65-77, 2002 
LABRUNA, M. B.; RESENDE J. S.; MARTINS, N. R. S.; JORGE, M. A. Cryopreservation of an avian spirochete strain in liquid nitrogen. Arquivo Brasileiro de Medicina

Veterinária, Zootecnia. v. 51, n. 6, p. 551-553, 1999.

LEVINE, J. F.; DYKSTRA, W. L.; NICHOLSON, R. L.; WALKER, R. L.; MASSEY, G. Attenuation of Borrelia anserina by serial passage in liquid medium. Research in Veterinay Science, v. 48, n. 1, p. 64-69, 1990.

MARCHOUX, E.; SALIMBENI, A. La spirillose des poules. Annales de l'Institut Pasteur, v. 17, p. 569-580, 1903.

MARCONI, R. T.; GARON, C. F. Phylogenetic analysis of the genus Borrelia: a comparison of North American and European isolates of Borrelia burgdorferi. Journal of Bacteriology, v. 174, p. 241-244, 1992.

MARTI RAS, N.; LASCOLA, B.; POSTIC, D.; CUTLER, S. J.; RODHAIN, F.; BARANTON, G.; RAOULT, D. Phylogenesis of Relapsing fever Borrelia spp. International journal of systematic bacteriology, v. 46, n. 4, p. 859-865, 1996.

MARZAGÃO, G. A procura do agente causador de Doença de Lyme no Brasil. 2001. 79 p Dissertação (Mestrado) - Instituto de Ciências Biomédicas, Universidade de São Paulo, São Paulo, 2001.

NOPPA, L.; BURMAN, N.; SADZIENE, A.; BARBOUR, A. G.; BERGSTROM, S. Expression of the flagellin gene in Borrelia is controlled by an alternative sigma factor. Microbiology, v. 141, p. 85-93, 1995.

PASTER, B. J.; DEWHIRST, F. E.; WEISBURG, W. G.; TORDOFF, L. A.; FRASER, G. J.; HESPELL, R. B.; STANTON, T. B.; ZABLEN, L.; MANDELCO, L.; WOESE, C. R. Phylogenetic analysis of the spirochetes. Journal of Bacteriology, v. 173, p. 6101-6109, 1991.

PATRICAN, L. A. Absence of Lyme disease spirochetes in larval progeny of naturally infected Ixodes scapularis (Acari:Ixodidae) fed on dogs. Journal of Medical Entomology, v. 34, n. 1, p. 52-55, 1997.

PIESMAN, J.; SINSKY, R. J. Ability to Ixodes scapularis, Dermacentor variabilis, and Amblyomma americanum (Acari: Ixodidae) to acquire, maintain, and transmit Lyme disease spirochetes (Borrelia burgdorferi). Journal of Medical Entomology, v. 25, n. 5, p. 336-339, 1988. 
PROWAZEK, S. V. Contribuição para o estudo do desenvolvimento do Spirochaeta gallinarum. Memorias do Instituto Oswaldo Cruz, v. 1, p. 79-80, 1909.

SAMBRI, V.; MARANGONI, A.; OLMO, A.; STORNI, E.; MONTAGNANI, M.; FABRI, M.; CEVENINI, R. Specific antibodies reactive with the 22-Kilodalton major outer surface protein of Borrelia anserina Ni-NL protect chicks from infection. Infection and Immunity, v. 67, n. 5, p. 2633-2637, 1999.

SA'IDU, L.; AGBEDE, R. I. S.; ABDU, A. P. Prevalence of avian spirochetosis in Zaria. Israel Journal of Veterinary Medicine, v. 50, p. 39-40, 1995.

SAKHAROFF, M. N. Spirochaeta anserina et la septicemie des oies. Annales de l'Institut Pasteur, v. 5, p. 564-566, 1891.

SCHWAN, T. G. Ticks and Borrelia: model systems for investigating pathogen-arthropod interactions. Infectous Agents and Diseases, v. 5, n. 3, p. 167-181, 1996.

SONENSHINE, D. E. Biology of Ticks, New York: Oxford University Press, 1991. v. 1. $447 \mathrm{p}$.

SONI, J. L.; JOSHI, A. G. A note on strain variation in Akola and Jabalpur strains of Borrelia anserina. Zentralblatt Veterinarmedizin Reihe B, v. 27, n. 1, p. 70-72, 1980.

STEERE, A. C.; COBURN, J.; GLICKSTEIN, L. The emergence of Lyme disease. European journal of clinical investigation, v. 113, n. 8, p. 1093-1101, 2004.

STROMDAHL, E.Y.; WILLIAMSON, P. C.; KOLLARS JR., T. M.; EVANS, S. R.; BARRY, R.K.; VINCE, M. A.; DOBBS, N. A. Evidence of Borrelia lonestari DNA in Amblyomma americanum (Acari: Ixodidae) removed from humans. Journal of clinical Microbiology, v. 41, n. 12, p. 5557-5562, 2003.

TALHARI, S.; SCHETTINI, A. P. M.; PARREIRA, V. J. Eritema crônico migrans. Doença de Lyme: estudo de três casos. In: CONGRESSO BRASILEIRO DE DERMATOLOGIA, 42., 1987, Goiânia. [Resumo...] p. [3].

VARELA, A. S.; LUTTRELL, M. P.; HOWERTH, E. W.; MOORE, V. A.; DAVIDSON, W. R.; STALLKNECHT, D. E.; LITTLE, S. E. First culture isolation of Borrelia lonestari, putative agent of southern tick-associated rash illness. Journal of clinical Microbiology, v. 42, n. 3, p. 1163-1169, 2004. 
WEBER, K. Aspects of Lyme borreliosis in Europe. European journal of clinical microbiology \& infectious diseases, v. 20, n. 1, p.6-13, 2001.

YOSHINARI, N. H.; ABRAO, M. G.; BONOLDI, V. L.; SOARES, C. O.; MADRUGA, C. R.; SCOFIELD, A.; MASSARD, C. L.; DA FONSECA, A. H. Coexistence of antibodies to tick-borne agents of babesiosis and Lyme borreliosis in patients from Cotia county, State of Sao Paulo, Brazil. Memorias do Instituto Oswaldo Cruz, v. 98, p. 311-318, 2003.

YOSHINARI, N. H.; BARROS, P. J. L.; GAUDITANO, G.; FONSECA, A. H. Report of 57 cases of Lyme-like disease (LLD). Brazil. Arthritis and rheumatism, v. 43, p. 188, 2000.

YOSHINARI, N. H.; BONOLDI, V. L. N.; BARROS-BATTESTI, D.; SCHUMAKER, T. T. S. Doença de Lyme-símile no Brasil. Revista Brasileira de Reumatologia, v. 39, p. 57-58, 1999.

YOSHINARI, N. H.; OYAFUSO, L. K.; MONTEIRO, F. G.; DE BARROS, P. J.; DA CRUZ, F. C.; FERREIRA, L. G.; BONASSER, F.; BAGGIO, D.; COSSERMELLI, W. Doença de Lyme. Relato de um caso observado no Brasil. Resvista do Hospital das clinicas Faculdade de Medicina de Sao Paulo, v. 48, p. 170-174, 1993.

YOSHINARI, N. H.; BARROS, P. J.; YASSUDA, P.; BAGGIO, D.; STEERE, A. C.; PAGLIARINE, R. C.; COSSERMELLI, W. Epidemiological study of Lyme disease in Brazil. Resvista do Hospital das clinicas Faculdade de Medicina de Sao Paulo, v. 47, p. 71-75, 1992. 